\title{
8. Symposium über Fragen der Cyanophytentaxonomie im Seenforschungsinstitut der ETHZ/EAWAG in Kastanienbaum (Schweiz), 2.-15. August 1979 Verhandlungsbericht
}

\section{Von Alfons Zehnder}

Manuskript eingegangen am 5. August 1982

\begin{abstract}
International Association for Cyanophyte Research IAC

Proceedings of the 8th Symposium for Cyanophyte Taxonomy, Kastanienbaum (Switzerland), August 1979

The 8th Symposium of the International Association for Cyanophyte Research IAC was attended by 29 specialists from 11 countries. The 19 oral presentations and discussions centered on the following themes: The basic principles of cyanophyte taxonomy ( 3 lectures), systematic problems of certain taxonomic groups ( 5 lectures), morphology (6 lectures) and ecology (5 lectures). The intensive discussions between representatives of the classical (european) taxonomic treatment of cyanophytes (based on morphological and ecological characteristics) and those representing the bacteriological study of 'cyanobacteria' were especially valuable. The central theme of the meeting was, however, the mutual microscopic study and discussion of problematic blue-greens from natural habitats, that were mostly collected during the three field trips into different areas of central Switzerland (Grimsel-Gotthard-Nufenen, Klewenalp, Gerzensee).
\end{abstract}

\section{Einleitung}

Das 8.Symposium der Internationalen Arbeitsgemeinschaft für Cyanophytenforschung wurde mit einer Gedenkstunde für Otto Jaag, den Begründer und begeisternden Spiritus rector der ersten sechs Tagungen, eröffnet. Dem 7. Symposium von 1976 in Lednice musste Otto Jaag aus gesundheitlichen Gründen fernbleiben, und am 31.Juli 1978 beschloss er sein reich erfülltes irdisches Leben. Edith Kann und der Berichterstatter zeichneten in ihren Gedenkworten in der Eröffnungssitzung Leben und Werk des Verstorbenen, insbesondere seine Bedeutung für die Blaualgenforschung $[11]^{* 1}$ ).

1) Für die mit Stern bezeichneten Referenzziffern siehe Literaturverzeichnis am Schluss des Artikels, S. 320 . 
Die folgende Liste umfasst sämtliche Teilnehmer, auch Gäste, die der Veranstaltung nur kürzere Zeit folgten:

Dr. Asta Almestrand, Lund, Schweden

Ms. Susan E. Campbell, Boston, Mass., USA

Dr. Tsang-Pi Chang, Plön, BRD

Dr. Germaine Cohen-Bazire-Stanier, Paris, Frankreich

Dr. Pierre Compère, Meise, Belgien

Fil. Lic. Gertrud Cronberg, Lund, Schweden

Dr. Einer Fjerdingstad, Virum, Dänemark

Prof. Dr. Stjepko Golubić, Boston, Mass., USA

Dr. Michael Herdman, Gif-sur-Yvette, Frankreich

Dr. Barbara Hickel, Plön, BRD

Dr. František Hindák, Bratislava, ČSSR

Dr. Nagaraj Jeeji Bai, Madras, Indien

Dr. Edith Kann, Wien, Oesterreich

Dr. Jiří Komárek, Třeboň, ČSSR

Dr. Jaroslava Komárková, Třeboň, ČSSR

Dr. Jørgen Kristiansen, Kopenhagen, Dänemark

Dr. Leif Kronborg, Uppsala, Schweden

Prof. Dr. Ralph A. Lewin, Woods Hole, Mass., USA

Dr. Maria-Elisabeth Meffert, Plön, BRD

Dr. Dieter Mollenhauer, Biebergemünd, BRD

Dr. Hans-Rudolf Preisig, Zürich, Schweiz

Dr. Olivier Reymond, Genf, Schweiz

Ms. Rosmarie Rippka, Paris, Frankreich

Dr. Maria Roussomoustakaki, Athen, Griechenland

Dr. Ferdinand Schanz, Zürich, Schweiz

Prof. Dr. Roger Y. Stanier, Paris, Frankreich

Dr. Urs Uehlinger, Winterthur, Schweiz

Dr. Alfons Zehnder, Neuenhof, Schweiz

Dr. Ulrich Zimmermann, Zürich, Schweiz

Für die Organisation und Administration sorgten Dr. Hans Rudolf Bürgi, Dr. Peter Bossard, Fräulein Beatrix Egli, Dr. Urs Uehlinger und der Berichterstatter.

Aufgrund früherer Erfahrungen hatte man darauf verzichtet, für das 8 . Symposium zum vorneherein besondere Themen aus dem Bereich der Cyanophytentaxonomie festzulegen. Trotzdem ergab sich ein deutlicher inhaltlicher Schwerpunkt: Die Probleme um die Grundlagen der Blaualgentaxonomie, die sich mit den beiden Begriffen «Cyanophyten» - «Cyanobakterien» umschreiben lassen.

Das Thema war schon am 7. Symposium in Form einer «Diskussion am runden Tisch» besprochen worden [12]*, wurde diesmal von Brian A. Whitton, der an der Teilnahme verhindert war, in einem Brief wieder aufgegriffen und in besonderen Referaten fortgeführt. Es durchzog aber auch die Diskussionen weiterer Referate. Dass kompetente Verfechter beider Standpunkte am Symposium teilnahmen, wurde als besonders wertvoll empfunden. 
Methodisch-arbeitstechnisch wurde auch diese 8.Arbeitstagung möglichst als Workshop gestaltet: Im Zentrum standen gemeinsame Arbeit und Diskussion am Mikroskop und Meinungsaustausch in kleinen Gruppen. Die Früchte derartiger Arbeit lassen sich in einem Bericht nicht leicht festhalten. Aber so wertvoll die im folgenden Abschnitt zusammengefassten Referate zweifellos waren, möchten wir doch der Arbeit am Mikroskop für unsere Anliegen die grössere Bedeutung beimessen. Das bedeutet, dass gemeinsame Arbeit an konkret vorliegenden CyanophytenMaterialien auch in Zukunft Basis unserer Veranstaltungen bleiben soll.

\section{Referate}

\subsection{Grundlagen der Cyanophytentaxonomie}

Komárek, J.: Some problems in the taxonomy of blue-green algae

In the last 20 years, the progress in algal systematics has manifested itself in the endeavour of application of new experimental methods to the taxonomical studies, and in the use of the possibly most objective and precise criteria for the evaluation of different taxa. Both tendencies are highly desirable, but they also introduce many new problems and some confusion into the systematics.

In spite of the modernization of algal taxonomy we must accept and keep some principles, the respectance of which is indivisible from taxonomical work:

At first, it is the service character of the system for ecological, physiological and biochemical studies. We must therefore determine such sets of individuals that are defined by their morphological or biochemical features and to which it is possible to ascribe the state of solitary, independent and limited taxa. The stated taxa serve as the basic operational units, and they are designed by valid symbols (names) which enable their univocal and comparable representation in any ecological, physiologi$\mathrm{cal}$ and biochemical studies.

The species is the basic taxonomical operational unit. We must therefore define the variability of both their cytomorphological features and physiological properties. The aim of taxonomical work is not only the elaboration of a review of the existing representatives of one group of organisms, but also the summarization of all available knowledge on their morphological, physiological and ecological diversity. The use of all appropriate methods and the discovering of correlations between the sets of different characters represent therefore the only methodological approach to the elaboration of a correct and satisfactory system. The univocal definition and the statement of diacritical features of different taxa, existing in different natural biotopes (niches) and transferable into the cultures, is the consequent, highly important part of the taxonomical work.

Therefore, the following procedures should be applied to the evaluation of the material:

1. The agglomeration of all possible data on the species studied. Fundamental is the morphological definition based on the nomenclatorial type. But its completion by definition of the morphological and physiological variability and by the ultrastructural and ecophysiological characters is most desirable. The confrontation of results 
obtained at least by two different methods and the verification of correlations between various features are both necessary.

2. The use of statistical methods and the application of diversity coefficients and biometrical procedures are inevitable in the definition of taxa. Many examples in the papers of Jaag, Fjerdingstad, Golubić, Kondrateva and others are quite convincing and exemplary.

3. The species is designated as the basic taxon. The different species are existing groups of individuals, characterized and defined by a set of common properties; they must be definable consonantly both in natural biotopes and in clonal cultures. Therefore, we can characterize them only by stable morphological, biochemical and/or ecological hiati, and to classify the strains, differing by quantitative changes as mere the links of one continual variation range of one species. Or, in other words, we must define the stable boundaries between different species. Of course, qualitative differences are preferable to quantitative changes in various properties.

4. We must accept consistently the monothetical concept of taxa. This means that the definition (description) of a superior taxon must summarize the features of all the subordinate taxa. Violation of this principle leads to a confused system in which the limits of different taxa overlap and prevent the univocal definition of taxa and their classification in the coded system.

5. Agreed rules must be used to the designation of different taxa. The hitherto satisfactory prescriptions, usable both in ecological and experimental practice, are those prescribed by the Code of botanical nomenclature. The mere change of the name 'Cyanophyceae' into 'Cyanobacteria' is acceptable, when the greater relation of blue-greens to bacteria as to eucaryotic algae will be proved (which is, however, not yet the case: comp. cell wall structure, structure of cytochrome c, structure of thylakoids, presence of chlorophyll a, ecological significance, etc.). However, when we accept the bacteriological rules at whole to the designation of cyanophycean strains (what is not usable in hydrobiological and ecological research), we obtain two different, not comparable systems. Such a practice is without doubt a step backward.

When we confront all these theoretical principles with the present system of coccal blue-green algae, we discover a confused situation:

1. There exists a great number of species that have been described within more than 150 years from the natural specimens. Many of them merely represent morphological deviations and ecomorphoses, described only in individual populations, without any knowledge of their variability. Such taxa are presently quite common in the system of blue-green algae and they are not comparable with the few species that have been studied in detail by modern methods.

2. In many, particularly experimentally oriented papers were used quite casually the names according to the simplified classification experiment of Drouet [1]. And many experimentators even do not compare their material in the microscope with the characteristics of the species; between the few strains of the so-called 'Anacystis nidulans' and 'Agmenellum quadruplicatum' do not exist any morphological differences. It is necessary to note, that Drouet [1] himself did not use the name Anacystis nidulans a year after its introduction in the phycological literature by Kratz and 
Myers [2]. If we look at the abstracts of algological literature we can see that the amount of papers with this phantasmal name has not yet decreased.

3. The coccal blue-green algae have morphologically simple cells, and they are sometimes variable, frequently in the most striking features (size of cells, ability to produce the sheaths under different conditions, colour of mucilaginous envelopes, etc.). The recognition (and definition) of different species, therefore requires extensive investigations both of natural populations and clonal cultures. This kind of work is still miles away from the final solution. It is clear that such studies will introduce many taxonomical transfers and nomenclatural changes in the existing system. Such changes are, of course, quite unpopular and lead to a criticism of the systematics.

4. The traditional superstition about the cosmopolitism and wide ecological tolerance of the majority of species has led to the common use of the European and North-American determination keys all over the world. Many morphologically similar species that are, however, distinguishable ecologically, geographically and even by their morphological variation, have been designed by one simple name. Parallely to the ecologically conditioned deviations, considered as solitary species, we now meet, on the other hand, types which are undeterminable. If we study carefully the microflora of blue-green algae from any natural biotope (and not only from the algologically less known areas), we encounter many such types.

The present situation in taxonomy of blue-green algae can be solved only by the combined studies of solitary species both in cultures using different strains (physiological variation, cytology, etc.), and in different populations in natural conditions (morphological variability, ecological properties, etc.) (Autorreferat)

\section{REFERENCES}

1 Drouet, F., and Daily, W.A.: Revision of the Coccoid Myxophyceae. Butler Univ. bot. Stud. 12, 1218 (1956).

2 Kratz, W.A., and Myers, J.: Nutrition and Growth of Several Blue-Green Algae. Am. J. Bot. 42, 282 287 (1955).

Address of the author: Dr. J. Komárek, Dept. of Microbiology, CSAV, Dukelska 145, 37982 Třeboň, CSSR.

Diskussion. Golubić: Wir begegnen in der Literatur zwei gleich üblen Extremen: Auf der einen Seite wurden Ökotypen ohne Hinweis auf ihre Variabilität als Arten beschrieben, auf der anderen Seite wurden ähnliche Formen oft ohne sorgfältige Untersuchung zu einem Taxon vereinigt. Immerhin ist das Problem auf dem Artenniveau relativ einfach, weil hier nur aufgrund beobachtbarer Fakten zu entscheiden ist. Auf dem Gattungsniveau ist das Problem komplizierter, weil zu den Fakten die (verschiedenen) Auffassungen der Taxonomen treten. Mollenhauer verweist auf die Problematik des Artbegriffs bei Cyanophyten. Während er bei Eukaryonten aus der Natur abgeleitet werden kann (sexuelle Fortpflanzung), basiert er bei den Cyanophyten auf Konvention. Stanier und seine Mitarbeiter haben etwa 50 Synechococcus-Stämme in Kultur. Sie lassen sich weder licht- noch elektronenmikroskopisch unterscheiden, wohl aber sicher und klar aufgrund der Basenzusammensetzung ihrer DNS. Komáreks Kulturensammlung enthält zahlreiche Stämme, die auf je ein Individuum einer einzigen Population zurückgehen und die unter sich kleine Unterschiede zeigen. Aber rechtfertigt sich da schon die Aufstellung neuer Taxa? Stanier: Nur der Vergleich zahlreicher Stämme kann zu sicherem Urteil führen; die Analyse eines einzelnen Stammes führt nicht weiter. 
Golubić, St.: Cyanophyta or cyanobacteria - recommendations for taxonomic treatment of greater prokaryotes

Strukturell mögen Cyanophyten Bakterien (Cyanobakterien) sein, funktionell sind sie Algen; sie haben schon früh im Präkambrium die Photosynthese «erfunden». Der Artbegriff ist bei ihnen mit vielen Missverständnissen behaftet, ist aber auch hier nötig als Verständigungsmittel über Lebensformen in der Natur.

Im Evolutionsprozess entstehen neue Arten als Folge neuer ökologischer Nischen. Als Realität entwickelt sich in ihnen aber eine neue Population, an der sich aus verschiedenen Blickwinkeln verschiedene Teilaspekte betrachten lassen wie Morphologie, Genetik, Physiologie, DNS-Komponenten, biochemische Zusammensetzung. Physiologen, Genetiker usw. müssen sich bewusst sein, dass sie bei ihren Arbeiten Einzelaspekte auswählen, weil sie den Gesamtkomplex «Art» nicht erfassen können. Die Artenbildung ist ein kontinuierlicher evolutiver Prozess, wobei die Genaustauschrate die Evolutionsrate bedingt. Das führt zu den bekannten Problemen um die gegenseitige Abgrenzung von Arten, die sich praktisch in Benennungsschwierigkeiten für Übergangsformen äussern. Daraus lässt sich die Forderung ableiten, Übergangsformen nicht ins Zentrum taxonomischer Studien zu stellen.

Für die eindeutige Definitionsmöglichkeit von Arten bedeutete die Möglichkeit von Klonkulturen in vitro einen Durchbruch. Dabei fragt sich allerdings, wie repräsentativ Klonkulturen sind. Überdies gibt es heute keine Kulturensammlung, welche auch nur annähernd die ganze bekannte Cyanophytenvielfalt in der Natur repräsentiert. Bei Vergleichen mit Bakterien ist zu beachten, dass viele Blaualgen Vielzeller sind: Bei ihnen sind Wachstum und manche anderen Funktionen lokal getrennt, aber funktionell aufeinander angewiesen. So brauchen die Heterocysten ihre vegetativen Nachbarzellen und umgekehrt; oder während Teile einer Pflanze das Wachstum einstellen, verhalten sich andere Teile meristematisch. Solche Formen dürfen nicht in ihrer exponentiellen Wachstumsphase beschrieben werden, da sich ihre morphologischen Charaktere erst später deutlich ausprägen.

Soll der taxonomischen Bearbeitung höher entwickelter Prokaryoten, also grösserer Blaualgen, der Code der Botanischen [2] oder jener der Bakteriologischen [1] Nomenklatur zugrunde gelegt werden?

Der Botanische Code basiert auf geschichtlicher Betrachtung: Grundlage für die Definition eines Taxons sind seine erste Beschreibung und das Typusmaterial im Herbar. Bei allen Schwächen, die sich daraus ergeben, wird damit doch die Verbindung mit in der Natur lebenden Organismen bewahrt. Prokaryoten können in der Regel nicht herbarmässig konserviert werden. Der Bakterien-Code fordert daher die lebende Kultur als Grundlage für die Definition eines prokaryotischen Taxons. Man übersah dabei, dass Kulturen in vitro auch evoluieren können und vergass, die Darstellung der Geschichte der Kultur zu fordern. Damit verlor man den Zusammenhang der Typuskultur mit ihrem Herkunftsmaterial in der Natur. In dieser Hinsicht wirkt $\S 18 \mathrm{~h}$ des Bakterien-Codes verheerend.

Wie soll man zukünftig bei der Beschreibung neuer Taxa vorgehen? Anzustreben ist eine Kombination von Forderungen des Botanischen und des Bakterien-Codes, d.h., lebende Kulturen sollen auf ihr Herkunftsmaterial in der Natur zurückführbar sein. Grundlage für die Definition eines Taxons wäre damit die lebende Klonkultur 
mit ihrer Geschichte. Konkret bedeutet das: Ein neues, in der Natur gesammeltes Material wird in zwei Proben geteilt. Die eine wird mikroskopisch untersucht und beschrieben, in Formalin fixiert, z. T. evtl., herbarmässig präpariert und für spätere Vergleiche archiviert. Die zweite Probe wird als Ausgangsmaterial für die Kultur in vitro benützt. Dieses Vorgehen wird seit etwa 20 Jahren beim Aufbau der Algothek der EAWAG praktiziert ([3], S. 133). Es ist zwar mühsam, ermöglicht aber experimentelle Untersuchungen über die Variabilität einer Form, Vergleiche mit anderen Stämmen unter gleichen Umweltbedingungen und gewährleistet die Verbindung von Natur- und Kulturmaterial. Die Aufspaltung der Blaualgentaxonomie in eine «Naturtaxonomie» (auf der Grundlage des Botanischen Codes) und eine von ihr unabhängige «Kulturentaxonomie» (basierend auf dem Bakterien-Code) kann und muss verhindert werden.

\section{LITERATURVERZEICHNIS}

1 Lapage, S.P., u.a. (Hrsg.): International Code of Nomenclature of Bacteria. American Society for Microbiology, Washington 1975.

2 Staflen, F.A., u.a. (Hrsg.): International Code of Botanical Nomenclature. A. Oosthoek, Utrecht 1972 .

3 Zehnder, A.: 6. Symposium über Fragen der Cyanophytentaxonomie in Kastanienbaum, 3.16. August 1972. Schweiz. Z. Hydrol. 35 (1) (1973).

Adresse des Autors: Prof. Dr. S. Golubić, Dept. of Biology, Boston University Boston, Mass. 02215, USA.

Diskussion. Stanier äussert sich vorerst zum Artbegriff: Die Art ist eine Realität. 20\% der Bakterienarten sind euryök («loose» species), 80\% stenök («tight» species), belegen also eine enge ökologische Nische. Einige solche Stämme werden seit 40 Jahren in Kultur gehalten. Dabei zeigen sie eine erstaunliche Stabilität, die auch unter extremen Kulturbedingungen erhalten bleibt. Zur Frage des massgeblichen Nomenklatur-Codes: Die völlig verschiedene Arbeitsweise der Kommissionen, also eine administrativorganisatorische Frage, spielt mit hinein: Der Bakterien-Code wird von einer permanenten Kommission betreut, die rasch arbeitet. Die Kommission für den Botanischen Code kann aber auf einen Vorschlag oft erst nach 2-3 Jahren reagieren. Zur Frage der Veränderung der Kulturen in vitro: Bei Aufbewahrung in flüssigem Stickstoff bleiben die Organismen konstant. Man beherrscht heute diese Methode; sie funktioniert absolut sicher, man kennt bisher keine Anzeichen einer Evolution solcher Kulturen.

Stanier, R.Y., and Rippka, R.: A proposed system of generic designation based on studies on pure cultures of cyanobacteria [1]

On the basis of a comparative study of 178 strains of cyanobacteria, representative of this group of prokaryotes, revised definitions of many genera are proposed. Revisions are designed to permit the generic identification of cultures, often difficult through use of the field-based system of phycological classification. The differential characters proposed are both constant and readily determinable in cultured material. The 22 genera recognized are placed in five sections, each distinguished by a particular pattern of structure and development. (Autorreferat) 


\section{REFERENCE}

1 Rippka, R., Deruelles, J., Waterbury, J. B., Herdmann, M., and Stanier, R. Y.: Generic assignments, Strain Histories and Properties of Pure Cultures of Cyanobacteria. J. gen. Microbiol. 111, 1-61 (1979).

Address of the authors: Prof. Dr. R. Y. Stanier, R. Rippka, Institut Pasteur, 28, rue du Dr Roux, F-75724 Paris.

Diskussion. Von mehreren Votanten, u.a. von Golubić und Komárek, wurde festgehalten: die «klassische» Cyanophytensystematik, wie sie uns etwa in den Werken von Geitler [5]*, Desikachari [3]*, Bourrelly [2]* u.a. begegnet, in die z.B. Jaag [8]*, Golubić [6]*, Kann [9]*, Anagnostidis [1]* u.a. vermehrt ökologische Gesichtspunkte hineintrugen («ökologische Systematik»), und die Kulturenmethode, wie sie von der Schule Staniers vertreten wird, sind heute nicht mehr weit auseinander. Resultate guter Arbeiten beider Richtungen sind vergleichbar. Seit 20 Jahren konvergieren die beiden Methoden zusehends. Die fünf Sektionen, in welche die Schule Staniers in der vorliegenden Arbeit die Cyanophyten gliedert, entsprechen weitgehend Ordnungen der «klassischen» Systematik. Grössere Probleme bringt weiterhin die Gattungs- und Artensystematik. Mollenhauer: In der Praxis müssen Bestimmungsschlüssel und Diagnose unterschieden werden. Ersterer greift nur einzelne Merkmale heraus, die für die Unterscheidung ähnlicher Arten oft nicht genügen. Golubić: Zwei Arten können aufgrund der Literatur oft nur unterschieden werden beim Vorliegen ausführlicher Diagnosen. Die ursprüngliche, ausgezeichnete Diagnose einer Hyella-Art umfasste zwei Seiten. Sie wurde später auf wenige Zeilen verkürzt, dann in mehrere Sprachen übersetzt und verlor damit ihren informativen Wert. Ähnliche Fälle liessen sich aus verschiedenen Formenkreisen anführen. Stanier: Man muss möglichst viel Information aus dem Objekt selbst herausholen, wie das Rippka ausgezeichnet macht.

\subsection{Taxonomische Probleme einzelner Gruppen}

Komárek, J., Hinđák, F., and Ludvik, J.: Synechococcus diatomicola isolated from the Lake Gerzensee (Switzerland)

In 1978, Dr. Hindák isolated a coccal blue-green alga from the littoral of the peaty lake Gerzensee (Kanton Obwalden, Switzerland), which was growing epiphytically on Oedogonium and corresponded morphologically to Synechococcus diatomicola, described by Geitler [1] from Austria. The Austrian specimen grew on the dead frustules of diatoms in the wooden trough of a spring, at a temperature of $7-11^{\circ} \mathrm{C}$. It had not been found any more up to date. The specimens from Gerzensee were transferred into unialgal culture, and we have studied its morphological variability, reproducing process and cytological characters using the method of electron microscopy.

Furthermore, we have found a population of a very similar blue-green alga possessing much the same morphological features (only the cells were a little larger), in a small basin with water plants, filled with thermal water in Pieštany, western Slovakia. The blue-green alga was again growing epiphytically on the filaments of Oedogonium.

The cells of S. diatomicola from Gerzensee (fig. 1) were cylindrical with widely rounded ends, measuring 1.5-4.5 $\times 0.7-1.5 \mu \mathrm{m}$. They were situated more or less parallely with the substrate, growing solitarily, in rows of 3-4 cells or in irregular clusters. The cells were mostly embedded in a fine, diffluent mucilage without any structure (fig. le, f). After staining with methylene blue, the more agglomerated 
mucilaginous material was visible near the ends of the cells and round the cross walls, formed during the division process (fig. 1d). The cell content appears homogeneous in an optical microscope; sometimes it is slightly granular. In the laboratory subcultures, brown incrustations were visible round the cells or round the cell clusters (fig. $1 \mathrm{~g}-\mathrm{i}$ ). The cell division proceeds only perpendicular or slightly oblique to the longer axis of the cell. The daughter cells are morphologically identical. We did not find any asymmetrical cell division into two unequal parts as it is known, for

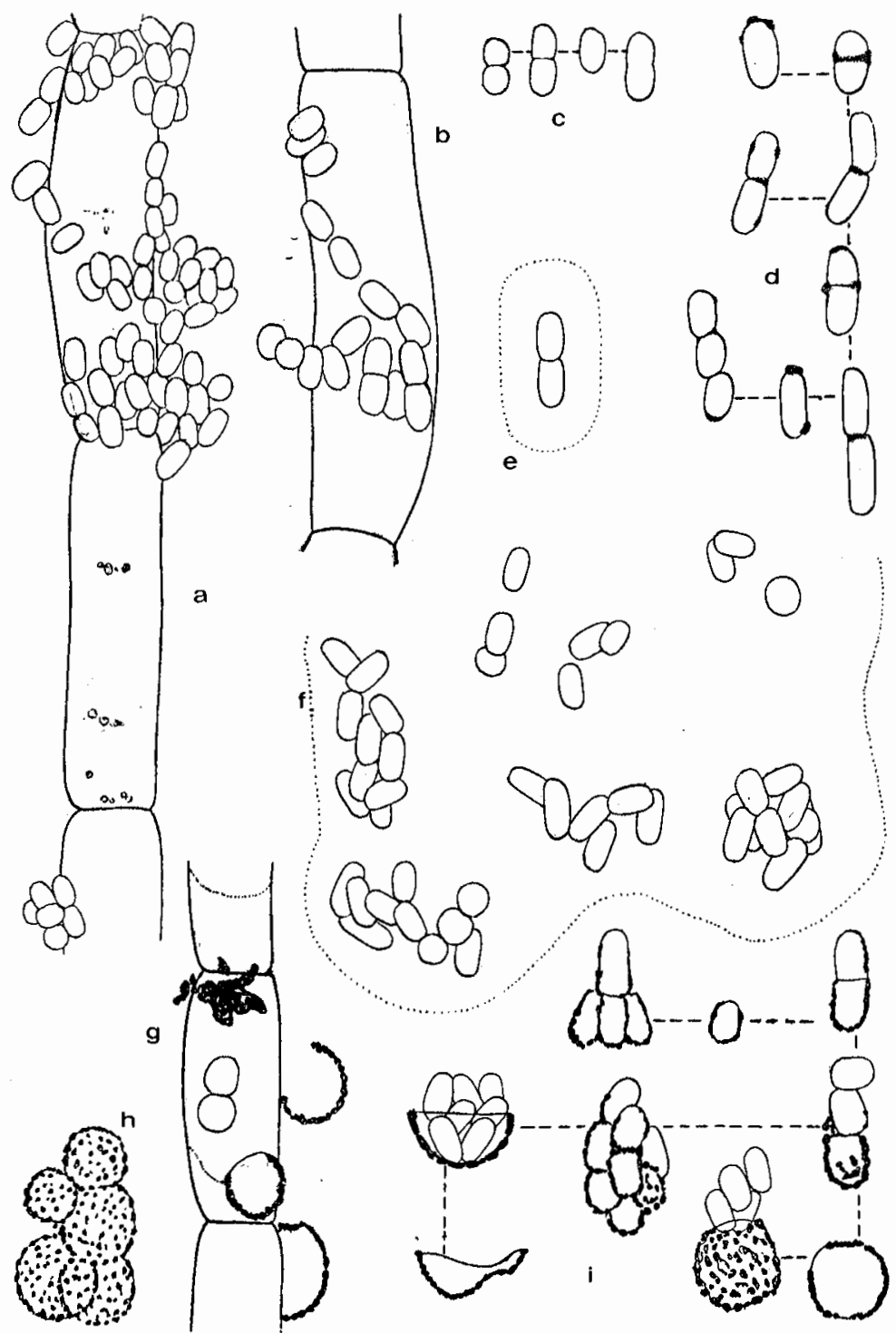

Figure 1. Synechococcus diatomicola from Lake Gerzensee and from Piełtany. 
example, in the type species of Synechococcus, S.elongatus, or in another wellknown Synechococcus species, S.leopoliensis (= 'Anacystis nidulans'), or in a few other unicellular blue-greens with more or less rod-like cells, such as Chamaesiphon and Geitleribactron. From this point of view, S. diatomicola is more related to Aphanothece, than to typical representatives of the genus Synechococcus.

The three materials of $S$. diatomicola exhibit only one important difference, namely in their temperature requirements. While Geitler's typical material grew at $7-11^{\circ} \mathrm{C}$, the material from Gerzensee was found in the peaty, dystrophic littoral with the summer temperature of about $18^{\circ} \mathrm{C}$ and that of Piestany grows in warm spring water at about $30^{\circ} \mathrm{C}$. In spite of that, the epiphytic mode of life and morphology are so uniform that also the taxonomical identity of all these materials is highly probable; the observed differences only seem to characterize different populations of the same species.

The ultrastructure of our alga (fig. 2) was not different from that in other coccal blue-green algae (comp., e.g., Gleason and Ooka [2]). 3-6 thylakoids are situated concentrically in the cells, the nucleoplasm contains few cyanophycin and polyphosphate bodies, and numerous polysomes distributed in it are recognizable in a few microphotos. The cell wall seems to be 2-layered on the cross sections; outside the cell wall, the mucilaginous envelope is visible. Its structure is highly variable in different cells, particulariy when cultivated under different conditions. The inner

\begin{tabular}{|c|c|c|c|c|c|c|c|}
\hline $\begin{array}{l}\text { CELL DIVISION } \\
\text { IN I PLANE }\end{array}$ & $\begin{array}{l}\text { CELL } \\
\text { SHAPE }\end{array}$ & $\begin{array}{l}\text { CELL } \\
\text { DIVISION }\end{array}$ & $\begin{array}{l}\text { INVOL. } \\
\text { FOAMS }\end{array}$ & $\begin{array}{l}\text { GROW/TH } \\
\text { FORM }\end{array}$ & $\begin{array}{l}\text { MUCIL. } \\
\text { ENVELOPES }\end{array}$ & $\begin{array}{l}\text { POLARITY } \\
\text { OF CELLS }\end{array}$ & TYPE SPECIES \\
\hline SYNECHOCOCCUS & & & & \begin{tabular}{|l} 
I solltary \\
(colonies)
\end{tabular} & $\begin{array}{c}- \\
\text { cor tine } \\
\text { diffluent }\end{array}$ & - & S. elongatus \\
\hline ROMEAIA & & & & pseudofil. & $\underset{+}{+}$ & - & R. elegans \\
\hline CYANOTHECE & & & & ‡ soilitary & $\begin{array}{c}- \\
\text { (or fine, } \\
\text { diffluent) }\end{array}$ & - & C. aeruginosa \\
\hline $\begin{array}{c}\text { (DACTYLOCOCCO- } \\
\text { PSIS) }\end{array}$ & & & & $\begin{array}{l}\text { mucilagin. } \\
\text { colonies }\end{array}$ & \begin{tabular}{|c|}
+ \\
fine, diffluent
\end{tabular} & - & D. smithii \\
\hline APHANOTHECE & & & & $\begin{array}{l}\text { mucilagin. } \\
\text { colonles }\end{array}$ & $\begin{array}{l}+ \\
\\
\text { lamellated. } \\
\text { later diffl. }\end{array}$ & - & A. microscopica \\
\hline TETAARCUS & & & & $\begin{array}{l}\text { mucllagin. } \\
\text { colonies }\end{array}$ & \begin{tabular}{|c|}
+ \\
fine, difflluent
\end{tabular} & - & T. ilsteri \\
\hline GEITLERIBACTRON & & & & $\begin{array}{l}\text { attached; } \\
\text { solit. cells }\end{array}$ & $\begin{array}{c}- \\
\text { (mucil. disc.) }\end{array}$ & + & G. periphyticum \\
\hline CHAMAESIPHON & & & & $\begin{array}{l}\text { attached, } \\
\text { solit. cells } \\
\text { or colonies }\end{array}$ & \begin{tabular}{|l|} 
diffluent \\
or firm \\
("pseudovag")
\end{tabular} & + & C. confervicola \\
\hline
\end{tabular}

Comparison of diacritical features between chroococcal genera with cells dividing in one plane in the subsequent generations. 
layer is thick and corresponds, by its structure and electron density, with the peptidoglycan (murein) layer found in other blue-greens. The outer layer is narrow, more electron transparent, sharply distinct at both the protoplasmic and external faces.

The cell division starts by a centripetal invagination of both the cytoplasmic membrane and the wide peptidoglycan layer (which is immediately followed by the external layer) into the protoplast. But this occurs without participation of the outer mucilaginous layers.

Let us compare this mode of reproduction with that in other blue-green algae, we may conclude that the principle of cell division is the same in all types of unicellular blue-green algae, including the so called exo- and endosporine types (comp., e.g., Komárek and Ludvík [3]). In all unicellular blue-greens, and probably also in the filamentous ones, only the system of $\mathrm{CM}$ and 2 cell-wall layers mentioned participate in the cell division. This follows from our results as well as from all published data concerning the genera Synechococcus (including 'Anacystis nidulans'), Synechocystis, Microcystis, Chroococcus, Geitleribactron, Chamaesiphon, Chroococcidiopsis, etc. On the other hand, all further outer layers of the cell-wall envelopes are greatly variable not only in different genera but also in the same species and even in the same strain. The reproduction process in simple coccal blue-greens can be therefore considered uniform and various genera can thus be distinguished only by the following differential features:

1. The shape of the cells and the way of cell division which can be realized: a) always in one plane perpendicular to the longer axis of the more or less elongated cell (Synechococcus, Aphanothece, Chamaesiphon), or b) in two mutually perpendicular planes in the subsequent generations (Synechocystis, Merismopedia), or c) in three or more planes in the subsequent generations (Gloeocapsa, Chroococcus, probably also Microcystis, Myxosarcina, Chroococcidiopsis, etc.).
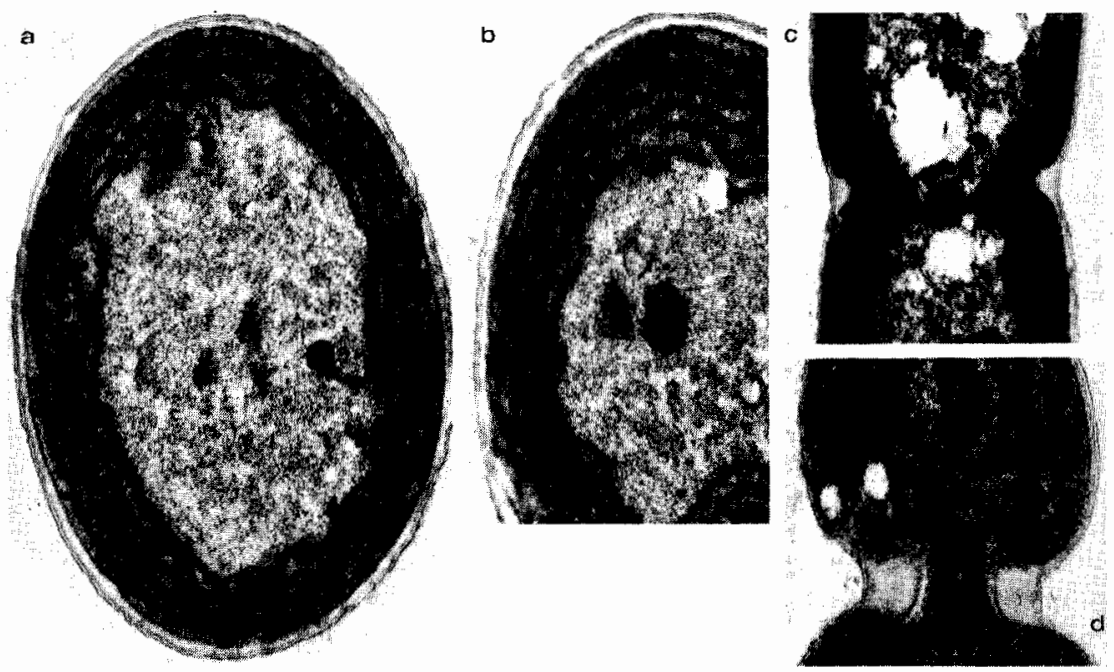

Figure 2. Cell structure of Synechococcus diatomicola. 
2. The asymmetrical or symmetrical cell division into two morphologically different or identical daughter cells. The asymmetrical cell division is common, e.g., in Synechococcus, Geitleribactron and Chamaesiphon. The symmetrical division occurs obligatorily in Aphanothece, Cyanothece and many genera with rounded cells.

3. The polarity of elongated cells. The bipolar shape and the sessile growth of cells is known, e.g., in Chamaesiphon, Geitleribactron, the polarized cells are typical of Aphanothece, Synechococcus, etc.

4. The ability to form the special mucilaginous envelopes round the cells, which can be variable in the same species in dependence on the environmental conditions, but the limits of this variability can be typical of individual genera. Examples of such variability can be found in the genera Chroococcus, Synechocystis, Microcystis, Chamaesiphon, Gloeocapsa, etc.

5. The mode of life and the ecological and qualitative ecophysiological characteristics of different types (planktonic, epiphytic species, etc.)

On the other hand, both the basic inner structure of the cyanophycean cell and the principle of its division seem to be highly uniform and, at the same time, unique for all blue-greens as a distinct group of organisms.

The monothetical characterization of taxa is the only concept in modern taxonomy that enables us to add continuously further data to the characteristics of the different species. If we apply this criterion to the existing system of blue-green algae and if we define consequently the diacritical features of genera according to the demonstrated results concerning the cell ultrastructure, we find many discrepancies in the present system. From this point of view, our $S$. diatomicola is more related to Aphanothece. On the table (p.276) is given the review of the diacritical characteristics of the main genera of chroococcal blue-greens dividing in the same plane in all generations. (Autorreferat)

\section{REFERENCES}

1 Geitler, L.: Eine ökologisch merkwürdige Cyanophycee, Synechococcus diatomicola n.sp. Öst. bot. Z. 100 (3), 292-301 (1953).

2 Gleason, F.K., and Ooka, M.P.: Cell cycle and cell wall formation in Synechococcus sp., a unicellular cyanophyte. Cytobiologie 16, 224-234 (1978).

3 Komárek, J., and Ludvík, J.: Cell structure and reproduction process in the blue-green alga Chamaesiphon. In press (1980).

Addresses of the authors: Dr. J. Komárek, Dept. of Microbiology, CSAV, Dukelska 145, 37982 Treboň, CSSR - Dr. F. Hindák, Dr. J. Ludvík, Ústav exper. biologie a ekologie SAV, Dúbravská cesta 26. 88534 Bratislava, CSSR.

Diskussion. Sie ergibt: Synechococcus diatomicola ist wohl eine seltene Form; so wurde sie von Kann nie, von Komárek nur zweimal, beide Male epiphytisch auf Oedogonium, gefunden. Die Einordnung in die Gattung Synechococcus ist als vorläufig zu betrachten. Da die Art in Kultur genommen werden konnte und sowohl in flüssigem Medium Z wie auf Z-Agar [10]* gut wächst, dürfte die Gattungszugehörigkeit bald zu klären sein. 
Kováčik, L.: Type of reproduction of Aphanocapsa, in comparison with the genera Chroococcus, Microcystis and Merismopedia

The necessity to solve some problematic features, in the taxonomy of Chroococcales, has been picked up by such earlier authors as Zehnder [11], Starmach [8], Golubić [2] and by others. One important problem which has not been solved yet, is the precise definition of some generic features of the coccal blue-greens with globular cells. This deficiency resulted in different opinions on the position and independence of the genera Chroococcus and Gloeocapsa as well as of Microcystis and Aphanocapsa.

Golubic [2] defined the differential features between the genera Chroococcus and Gloeocapsa with respect to different ways of cell division and to the production of extracellular gelatinous envelopes. The position of the genera Aphanocapsa and Microcystis has not been solved yet.

Padmaja [7] stimulated the solution of the question by her discovery that, in some benthic species of the genus Aphanocapsa, the cells divide in two mutually perpen-
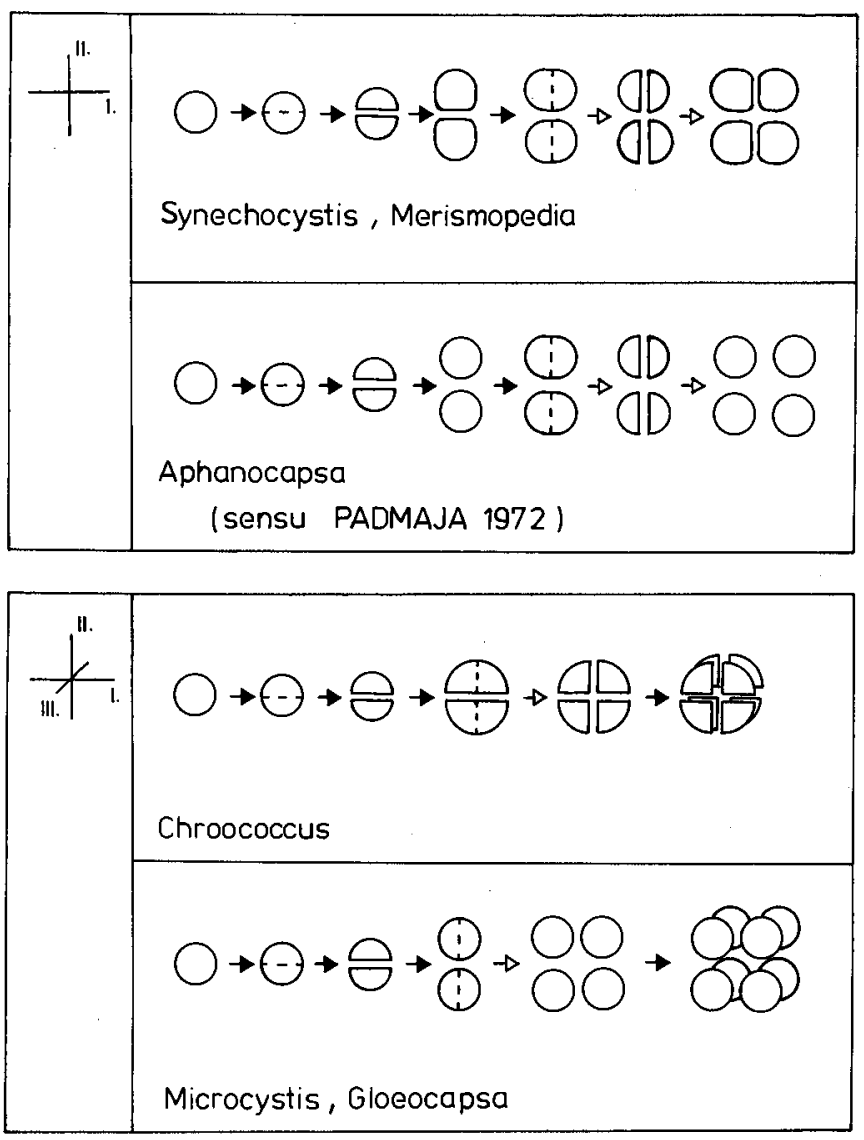

Figure 1. Schematic illustration of cell division in two and three successive generations. 
dicular planes; in the contrary to the genera Chroococcus and Gloeocapsa where the cells divide in three planes. For the genus Microcystis three planes of cell division are commonly presumed in literatur.

Komárek [5] discovered that the cells of the genus Synechocystis divide in two planes only, consequently the genus is related to the genus Merismopedia; from this it differs only by the absence of the mucilage which joins, in the genus Merismopedia, the cells into table-like colonies. A few strains of the genus Aphanocapsa, sensu Padmaja [7], are also related to the genus Synechocystis because its cells also divide in two planes.

The mode of division of cells of the genus Merismopedia was studied in detail by Geitler [1] and that of the genus Chroococcus by Vogel [10].

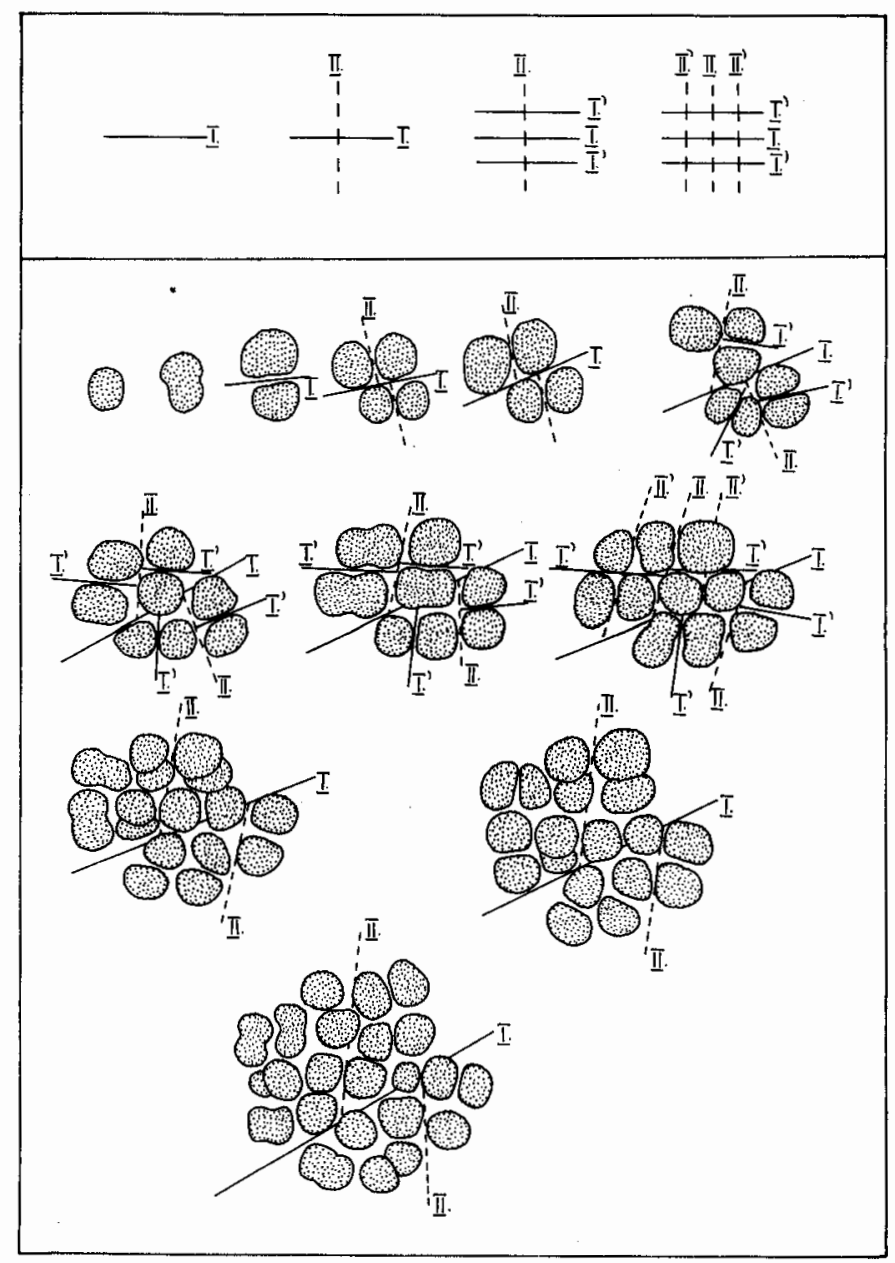

Figure 2. Cell division of Chroococcus prescottii, strain 9 BG in successive generations. 
I presume that the only solid criterion for the definition and separation of the genus Aphanocapsa from the genus Microcystis is the mode of cell division, in the succession of generations. On the other hand, in Chroococcus limneticus, the cell division is assumed to occur in two planes, and only rarely in three [4]. This fact attracted my attention to this problem.

Material and methods. For the study of the generic process I used the following strains: Microcystis aeruginosa, strain Hindák 1971/1; Chroococcus turgidus, strain Hindák 1971/52 and Chroococcus prescottii, strain 9 BG. The first and the second strain were supplied by the Culture Collection of the Department of Hydrobotany (Institute of Botany of the Czechoslovak Academy of Sciences) at Třeboñ; the last strain was kindly supplied by the Department of Microbiology, University of Queensland, Australia.

The reproduction processes of the cells of all strains were studied on agar plates, in the medium $\mathrm{Z}$ according to Zehnder [9] with $1.5 \%$ of agar. The cultivation was carried out in Petri dishes at $26^{\circ} \mathrm{C}$ and $4 \mathrm{Wm}^{-2}$ of PhAR irradiance in the cultivation equipment after Lukavský [6]. Division was observed on the agar plates under a microscope, at regular intervals. In addition to the cultivation experiments, I studied the cell division in living algae from nature.

Results and discussion. On the basis of the cultivation experiments and observations made, two groups of coccal blue-greens may be distinguished, which have globular cells plated in not lamellated mucilaginous envelopes (fig. 1). These two groups can be distinguished according to the number of planes during cell division in successive generations:

1. The genus Microcystis is the representative of the first group (type species is Microcystis aeruginosa (Kütz.) Lemm.). In this case, the cell division, in successive generations, proceeds in three planes which are mutually perpendicular. This feature of the genus Microcystis places it near to the genera Chroococcus and Gloeocapsa which possess, however, structured and lamellated mucilaginous envelopes, and near to the genus Eucapsis which produces regularly cubical colonies.

2. The other type agrees with the present concept of the genus Aphanocapsa (in the sense of Padmaja [7]). The group is related, by the mode of cell division both to the genus Synechocystis (which differs by its solitary cells forming neither thick homogeneous mucilage envelopes, nor mucilaginous colonies) and to the genus Merismopedia (which is characteristic by typical table-like colonies).

This second type seems to be defined sufficiently by the way of cell division, but it will be necessary to consider if the genus Aphanocapsa agrees enough with this concept and if it can keep its original name. It seems that it will be necessary to study thoroughly the way of cell division of the type species of the genus Aphanocap$s a$, i.e. A.parietina Näg. Highly useful would also be the revision of a greater number of the species, which correspond to the generic diagnosis of this new type.

The species studied by Padmaja [7], i. e. Aphanocapsa biformis, A.pulchra, A.rivularis will have to be joined to this new genus as well as the planktonic species Chroococcus limneticus, Ch.prescottii (fig.2) and Ch.dispersus which do not agree with the diagnosis of the genus Chroococcus. 
In some genera, however, the planes of cell division can alternate in various ways (e.g. Cyanostylon [3]); this is the case in more highly organized types which develop towards true branching. But such alternating planes of cell division never occur in simple coccal types. (Autorreferat)

\section{REFERENCES}

1 Geitler, L.: Über rechtwinkelige Schneidung von Scheidewänden und dreidimensionale Zellverbände. Öst. bot. Z. 98, 171-186 (1951).

2 Golubić, S.: Zwei wichtige Merkmale zur Abgrenzung der Blaualgengattungen. Schweiz. Z. Hydrol. 29, 176-184 (1967).

3 Golubić, S.: Personal communication (1979).

4 Huber-Pestalozzi, G.: Das Phytoplankton des Süsswassers. In: Die Binnengewässer XVI, 1.Teil, 342 p. Stuttgart 1938.

5 Komárek, J.: Taxonomic review of the genera Synechocystis Sauv. 1892, Synechococcus Näg. 1849, and Cyanothece gen. nov. (Cyanophyceae). Arch. Protistenk, 118, 119-179 (1976).

6 Lukavský, J.: Controlled cultivation of algae on agar plates. Arch. Hydrobiol., Suppl. 46, Algol. Studies 10, 90- 104 (1974).

7 Padmaja, T.D.: Studies on coccoid blue-green algae, II. In: Desikachary, T.V. (ed.): Taxonomy and biology of blue-green algae, p. 75-127. Madras 1972.

8 Starmach, K.: Zur Taxonomie der Chroococcales. Schweiz. Z. Hydrol. 29, 172-175 (1967).

9 Staub, R.: Untersuchungen an der Blaualge Oscillatoria rubescens DC. Schweiz. Z. Hydrol. 23, 83198 (1961).

10 Vogel, E.: Untersuchungen über die Teilungsrichtungen in Pollenmutterzellen und bei der Blaualge Chroococcus. Öst. bot. Z. 94, 2-29 (1947).

11 Zehnder, A.: Zur Systematik der Chroococcaceae. Schweiz. Z. Hydrol. 22, 365-379 (1960).

Address of the author: Dr. Ľ. Kováčik, Dept. of Botany CSAV, Dukelská 145, 37982 Třebon̆, CSSR.

Diskussion. Die Frage nach der taxonomischen Bedeutung der Teilungsrichtungen im Raum steht im Zentrum. Stanier: Merismopedia ist eine gut definierte Gattung, von der bisher leider keine guten EMAbbildungen existieren. Der charakteristische Teilungsmodus kann durch Mutation verlorengehen. Es gibt also eine «stabile» Merismopedia und daneben Merismopedia-ähnliche Formen, die instabil sind. Golubić: In der ursprünglichen Definition von Chroococcus sind die Teilungsrichtungen nicht erwähnt, in Definitionen anderer Gattungen sind sie festgehalten. Soll man nun die Gattung Chroococcus aufspalten in eine Gattung mit Zellteilung in zwei und eine mit Teilung in drei Dimensionen? Komárek: Das hängt von der Stufe $a b$, auf welche man dieses Merkmal in der Hierarchie der Merkmale stellt, und da besteht bisher keine einheitliche Auffassung. Stanier: Die Analyse der DNA-Basenanteile gäbe die Antwort.

\section{Almestrand, A.: Some comments on the taxonomy of planktic Microcystis}

The large-celled planktic species of the blue-green genus Microcystis, which are well-known for creating blooms in eutrophic lakes, are relatively few. However, the taxonomists who have examined them more closely have often arrived at divergent results. The latest comprehensive monograph is that of Komárek [2], whose demarcation of planktic Microcystis species has been generally adopted.

My own studies on the phytoplankton of eutrophic Swedish lakes gave me the opportunity to examine the large Microcystis species fairly closely. I often found it 


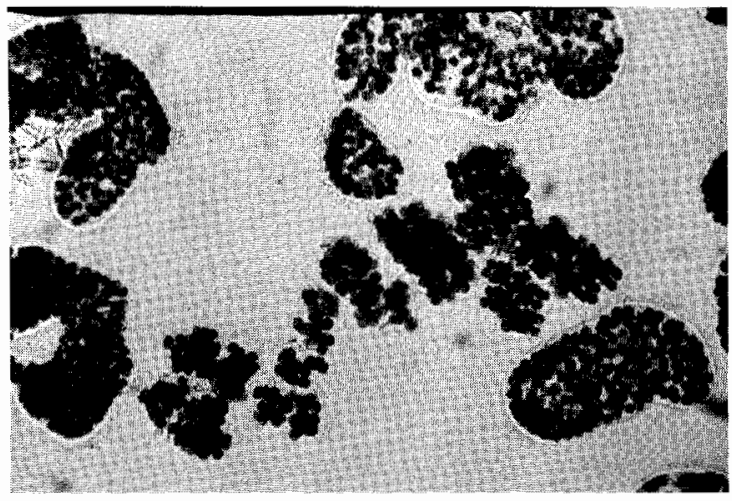

Figure 1. Microcystis wesenbergii and $M$. viridis.
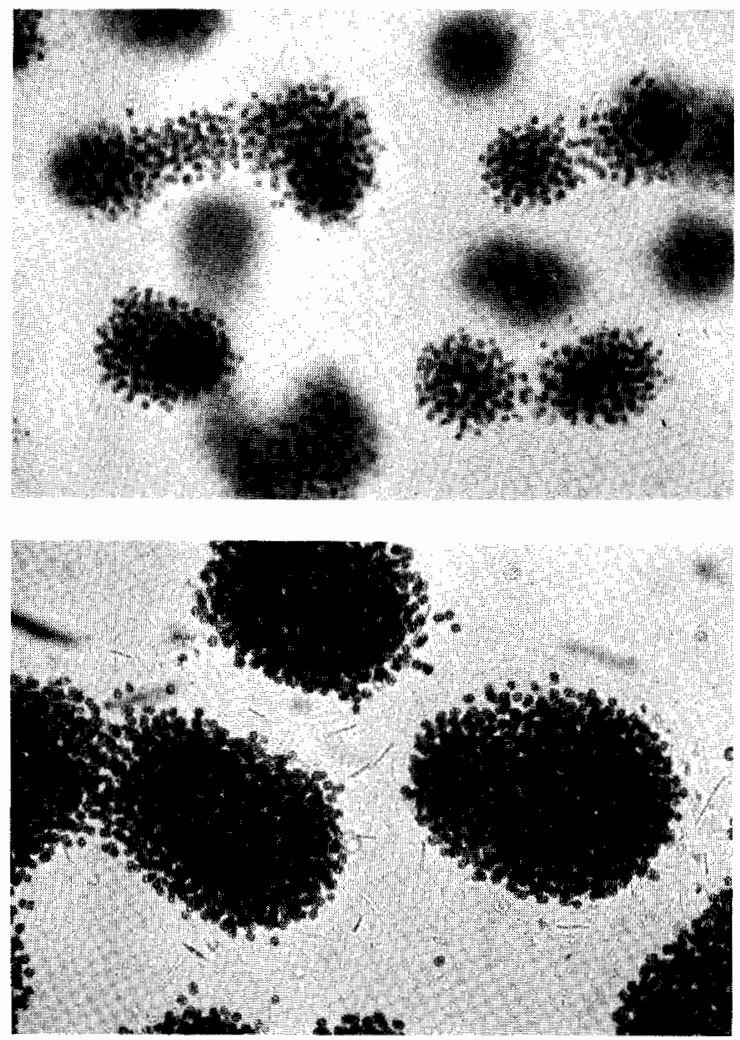

Figure 2. Microcystis botrys. In one of the photographs small epiphytes are to be seen in the mucilage. 
difficult to distinguish the different species - all very frequent - using Komárek's list of species.

I decided then to make a comparative study of the Microcystis species occurring in certain lakes. I collected samples from a number of lakes, all within the span of a few weeks, and examined them when they were still quite fresh. In this way I tried to avoid some of the damage that usually occurs to the colonies in old samples and also in preserved ones.

The two species M.viridis (A.Br.) Teiling and M.wesenbergii Komárek could be identified very easily (fig. 1). In addition I could distinguish a third form (fig. 2). It did not belong to $M$. viridis or to $M$. wesenbergii, nor to the common M. aeruginosa Kütz. However, it resembled a species, M. botrys, which was described by Teiling [5]. M.botrys was not accepted by Komárek [2], although Skuja [3, 4] reported it in his works on Swedish plankton. Other findings were later noted from Lakes Mälaren and Hjälmaren (Willén [6, 7]).

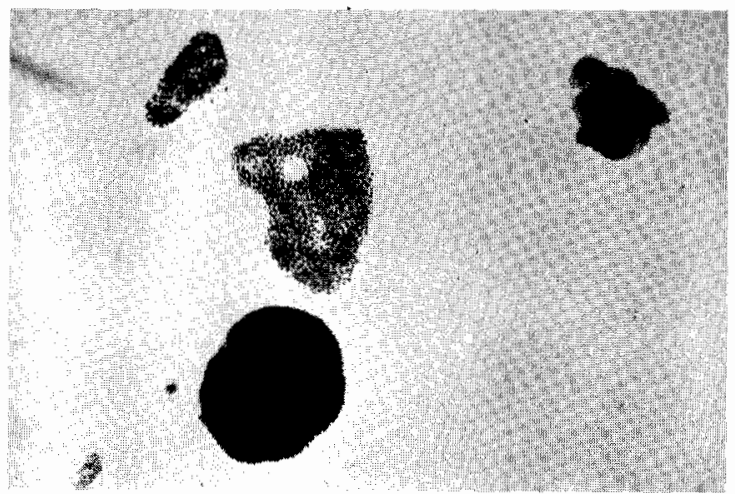

Figure 3. Microcystis aeruginosa f. flos-aquae with the typical colony form,

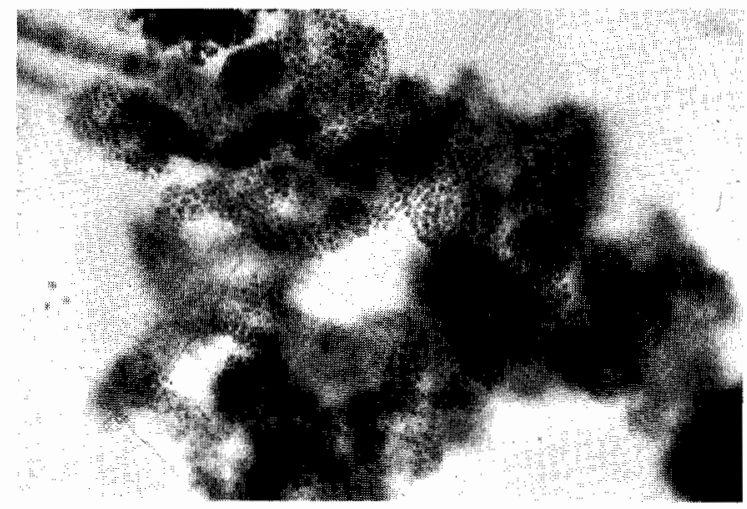

Figure 4. Microcystis aeruginosa f. flos-aquae with an irregular colony form. 


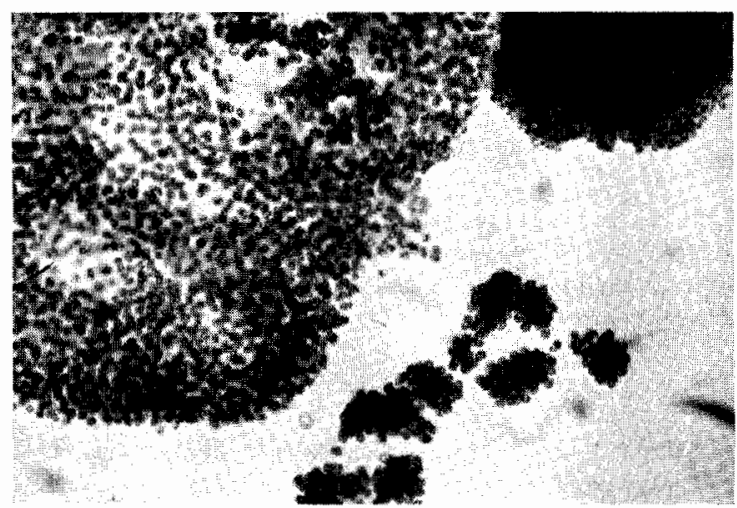

Figure 5. Microcystis aeruginosa. Two colonies with different cell sizes. Below to the right $M$. viridis.

Typically, M. botrys is composed of rounded or slightly elongated part colonies which lie close together. The cells of the third form show up very black under the microscope. The mucilage is relatively thick, often occupied by epiphytes, but has no sharp contour. The cells are distinctly larger than those of the M.aeruginosa form that is the most common in my samples.

The colonies of M.botrys observed in the lakes studied do not agree with the description of M.marginata (Geitler [1]) or of M.nováčekii (Komárek [2]). The colonies of M. marginata occur singly and are surrounded by mucilage with a more or less distinct margin. M. nováčekii is characterized by a wide band of mucilage with a clearly marked margin, and the cells are concentrated in the centre of the part colonies.

I am of the opinion that the Microcystis form occurring in these lakes should be identified as M. botrys. It belongs apparently to the M. aeruginosa group.

M. aeruginosa, as described by Komárek, is also to be found in my samples. Komárek distinguishes two forms, f. flos-aquae and f. aeruginosa. Without doubt the type frequent in the lakes studied is to be identified as f. flos-aquae (fig. 3) on account of the small cell size and the rounded colony form (cf. Komárek [2], table V). However, the appearance of the colonies varies considerably, probably with age (fig. 4).

In a few lakes I noticed a form of M. aeruginosa with larger cells (fig. 5), similar to f. aeruginosa according to Komárek. However, my material is so far too incomplete to give a definite answer.

My experience up to now would indicate that it is not impossible to distinguish the different large planktic Microcystis species, provided that the samples to be examined are fresh and collected during summer time. (Autorreferat)

\section{REFERENCES}

1 Geitler, L.: Cyanophyceae. In: Rabenhorst's Kryptogamen-Flora von Deutschland, Österreich und der Schweiz, Bd. XIV (1932).

2 Komárek, J.: Die taxonomische Revision der planktischen Blaualgen der Tschechoslowakei. In: Komárek, J., and Ettl, H.: Algologische Studien. Prag 1958. 
3 Skuja, H.: Taxonomie des Phytoplanktons einiger Seen in Uppland, Schweden. Symb. bot. upsal. 9, 3 (1948).

4 Skuja, H.: Taxonomische und biologische Studien über das Phytoplankton schwedischer Binnengewässer. Nova Acta R. Soc. Scient. upsal. (ser. IV) 16 (3) (1956).

5 Teiling, E.: Schwedische Planktonalgen. 3. Neue oder wenig bekannte Formen. Bot. Not. 1942, 63-68 (1942).

6 Willén, E.: Växtplanktonarter i Mälaren 1965 och 1969 (Phytoplankton in Lake Mälaren 1965 and 1969). Statens Naturvårdsverk PM (Sweden) (1973).

7 Willén, E.: Phytoplankton and environmental factors in Lake Hjälmaren, 1966-1973. Statens Naturvårdsverk PM (Sweden) (1976).

Address of the author: Dr. Asta Almestrand, Nyckelkroken 22, S-222 47 Lund, Sweden.

Diskussion. Komárek: Aufgrund von Variabilitätsstudien an Natur- und Kulturmaterial betrachtet Kondrateva Microcystis viridis und Microcystis wesembergii als "gute" Arten. Anderes MicrocystisMaterial zeigt eine grosse Variabilität mit fliessenden Übergängen zwischen einzelnen Formen. Kondrateva bezeichnet sie als Varietäten einer dritten Art, M. aeruginosa. Almestrand bekräftigt, sie unterscheide M. botrys aufgrund der Kolonieform von M. aeruginosa, der offensichtlich häufigsten Art.

Compère, P., Komárek, J., Walmsley, R. D., and Barlow, D. J.: Katagnymene mucigera, a new planktonic blue-green alga from South Africa

Katagnymene mucigera, a new planktonic blue-green alga is described and illustrated from material collected in South Africa. Comparisons are made with Oscillatoria ornata, Trichodesmium lacustre (=O.lacustris) and T.iwanoffianum, as it appears that forms with trichomes similar to those of this new species have been described from the USSR and the Philippines under the names O.ornata f. planctonica and O. lacustris var. solitaria. However, the new species is assigned to the genus Katagnymene, owing to the prominent mucus embedding the trichomes. A key of the five known species of Katagnymene is given, together with the formal latin diagnosis of the new species. Detailed data on the ecological distribution of this species in South Africa are provided. The fine structure (TEM) of the new species is described and illustrated. - The paper is published in full in Bull. Jard. bot. nat. Belg. $49(3 / 4)$ (1979). (Autorreferat)

Address of the author: Prof. Dr. P. Compère, Jardin Botanique National de Belgique, Domaine de Bouchout, B-1860 Meise, Belgium.

Diskussion. Sie dreht sich um die Frage der gegenseitigen Abgrenzung der Gattungen Oscillatoria, Katagnymene und Trichodesmium. Katagnymene besitzt im Gegensatz zu Oscillatoria eine dicke gelatinöse Scheide. Sie tritt immer in einzelnen Filamenten auf. Ähnliche oder gar gleiche Zellstruktur verbindet sie mit Trichodesmium. Dieses tritt in der Natur aber in bündelartigen Kolonien auf, deren Fäden durch Schleim zusammengehalten werden. Schon bei der Probenahme, vor allem aber beim Transport von fixiertem Material, zerfalien die Kolonien zum Teil in Einzelfäden ohne sichtbare Gelatinescheide. Aus solchem Material können keine sicheren taxonomischen Schlüsse gezogen werden. Golubic: Bei Trichodesmium sitzen die Gasvakuolen nie unmittelbar an den Querwänden der Trichome. Aus praktischen Gründen sollten Oscillatoria und Trichodesmium nicht in eine Gattung zusammengefasst werden. Die Trennung ist berechtigt aufgrund der Originaldiagnose Ehrenbergs für Trichodesmium sowie der $ð$ kologie und der unterschiedlichen Kolonienbildung. 
Mollenhauer, D.: Nostoc as a model for redefining genera in Cyanophyta Recent research in Cyanophyta has brought to light several shortcomings in current concepts of these organisms. This unique group obviously has its own taxonomic structure. In this respect it resembles the other procaryotes (bacteria). The specific taxonomic structure of Cyanophyta cannot be revealed by using methods which are derived from field research. Traditional outdoor study of blue-green algae is affiliated with concepts of early limnology. When this branch of biology arose its program was mainly synecological. Such tendencies also were authoritative in forest ecology, pedology, study of plant communities and landscape ecology. At that time this way of research was a reaction provoked by extremely 'atomistic' views in general biology. All the above mentioned enterprises in their holistic and typologic orientation have been very fruitful for science as a whole. However, it has been subsequently overlooked that holistic concepts deeply influence our mental attitude by indoctrinating investigators, i.e. by making perceptions conform to preconceptions. Thus, field study in the above mentioned 'classical' sense is biased by the pecularities inherent in our human manner to perceive the world around us. We transform our observations into well-defined entities of phenomena ('Gestalten'). Thus, traditional taxonomy is constrained to fragmentary insights. We sort out and place in our rubrics only a selection of those blue-green algae which happened to call our attention to their appearance. We may assume that our failure is not as severe as in the case of bacteriology if it were restricted by comparison only to those bacteria which can be detected by nothing but microscopic examination. But as far as we can see now, we really overlooked a lot of important Cyanophytes whose habitats do not coincide with portions of the biota which have been studied by traditional research. In this context the German concept of 'Landschaft' interferes. 'Landschaft' is the complex of geomorphologic, atmospheric, edaphic, organismic, and human aspects which altogether bring about the characteristic appearance of a special region. The term 'Landschaft' embraces the area in its totality, including terrestrial as well as aquatic components. There are different schemes of substructures of 'Landschaft'. All such substructures are in their turn typological concepts. And these very substructures have been used as guideline for the inventory of habitats of Cyanophyta (e.g. streams, plankton, soil). This is fully intelligible from our nature and from the history of science. But it is not according to the aim to find out the taxonomic structure inherent in Cyanophyta.

As a result of this reflection we can state that we have tried to understand the taxonomic structure of Cyanophyta by our own perception. This is an inappropriate approach. We now know that they are present in many sites where we cannot directly encounter them. Taxonomy therefore needs imagination. We have to imagine a world of Cyanophyta, a 'Landschaft' of Cyanophyta, not one of man. We have to imagine where they may be and try to collect them also in places where we cannot see them. Whether or not we were successful only can be stated in the laboratory. The latter, however, is also often very inappropriate for the study of Cyanophyta for its set-up has been designed for other purposes. The laboratory equipment therefore has to be completed and set up anew with regard to the proper demands of research in Cyanophytes. Nevertheless, we must rather radically change mind and method. Pure field work is not sufficient. Even a specialized laboratory is a 
means of research which we cannot longer spare. However, that revolution does not mean that we turn away from the only standard that we can have for suitable methods: the Cyanophyte and its properties. We always must adjust our study to the purpose to understand the organism. Submission to ritualized procedures of laboratory practice will cause another failure, as radical as that of field study dominated by ideology.

We hope to proceed to a reference system whose characters can be determined in the laboratory. We have no choice for we must have standardized conditions for description of taxonomic units. At present laboratory techniques only allow to discern a rather restricted diversity of different patterns of organization and life cycles. But without any doubt true clusters become apparent even in laboratory research. To name these clusters is a matter of convention, and it is compulsory for such a convention to be stable. Application of nomenclatural patterns which mainly are designed for the needs of higher plants has proved useless. A new scheme will be simpler, and it has to be appropriate. Pragmatically we may start with genera, for their naming is fully conventional. Thus, we may hope to agree upon this point first. Just as we decided no longer to use research methods whose dependence on the structure of our mind and eye is obvious, we also cannot continue to use generic boundaries simply because we got accustomed to use them. Moreover, many boundaries between genera have lost their importance as standards in the course of time. Active and vital taxonomy always tends to gradual blurring of its standards. They therefore need emendations from time to time, otherwise taxonomy gets paralyzed by dogmatism and formalism. When research in blue-green algae grew up from its first inadequate beginnings, taxa mainly were defined by means of contrasting pairs. This is the well-known Aristotelian way of categorizing things by diairesis. Prominent examples of this procedure are such pairs as 'animals with blood animals without blood', 'quadruped - not so', etc. The disadvantage is the predominance of per negationem characterizations. We know much better what a thing is not and get little information on its peculiarity and its very character.

This is quite true for the genus Nostoc. Vaucher separated it from other gelatinous plants by clearing up its differences from jelly fungi. Henceforth its nonfungal nature was fully recognized, advancing research cleared up its algal nature. But it was included in a heterogeneous complex of gelatinous algae. A next step was the separation from other gelatinous algae, such as Tetrasporales, etc. After having acknowledged a special group of blue-green algae the phycologists gave to Nostoc its characterization by contrast with other members of this group. Advancing science thus has brought to light a lot of information what Nostoc is not. However, so far there is no fully positive definition of this genus available that would comprise the whole range of organisms included in Nostoc. This is partly due to the canonizing effects of nomenclatural rules. It is true that we owe to Bornet, Flahaut and Thuret a substantial definition which summarized all the knowledge of that time. But it needs to be updated. Its limited application to natural situations becomes more and more obvious. This failure of traditional phycology is caused by overrating morphological characters compared with those of the developmental cycles in blue-green algae. Even today many new descriptions are based only on fragmentary knowledge of life cycles. 
At present, current identification keys and floras continue to understand by Nostoc those hormogonilean blue-green algae with cylindric trichomes and heterocysts that form plant masses by means of gelatinous matter whose size and shape is considerable and characteristic. Such a kind of definition is unusable in culture studies. On the other hand, Nostoc is one of the clusters which are discernable in the diversity of blue-green algae even under laboratory conditions. This is by no means necessarily so. There are other genera which fail in an examination in culture. Their characteristic features disappear when they are grown axenically. Thus, we need another characterization of Nostoc.

Careful examination of the wide range of hormogonalean diversity in the course of two decades of investigation in the genus Nostoc has convinced me to follow similar concepts as have been proposed by Lazaroff and Vishniac, Kantz and Bold, and especially the Stanier group. This may appear strange at first glance, but there is no way to become aware of generic characters by solely working in the field.

Nostoc is to be defined as a hormogonalean blue-green organism with cylindric and unbranched heterocystous trichomes, without the capacity of longitudinal cell division, with a developmental cycle of at least two alternating phases, one trophic (not for propagation, immobile, i.e. sessile or sedentary) and one generative (not necessarily with active motility, but mobile). The second phase may be a hormogonium, but it need not be. Facultative characters include even the formation of gelatinous plant masses (a feature which has been considered so important by field phycologists). All further characters are accessory. It is of no significance for the Nostocacean nature of a given organism if they are lacking.

However, tracing out the taxonomic structure of the whole of Cyanophyta is one thing, and understanding the ecological rôle of a special blue-green alga in nature is another. From laboratory practice there is no access to the questions of functioning and evolutionary development of the biosphere. Knowledge of biocoenotic situations means finding out the reasons and circumstances of the very part which has been assigned to a special organism. It is more than metaphoric when we allude to parallels in history. Study of a single person, knowledge of someone's inheritance, abilities, and disposition is not sufficient for understanding his historical importance. We can find out what sort of rôle he was principally able to play; but whether he really got this part or not cannot be derived from such knowledge. We must know the circumstances.

Knowledge of such circumstances is provided by field research. All life conditions taken as a whole may be called the ecological niche. Such niches are the counterparts of what taxonomists in Cyanophyta for a long while used to call 'species'. Thus, traditional taxonomy of Cyanophyta has reported on something like imprints of the biospherical structure in the whole of diversity of blue-green algae. Availability of life conditions and discernibility of clusters were the guiding principles. However, their guidance remained unconscious. There are also taxa in Cyanophyta that do not represent counterparts of niches. In many cases, especially when reinvestigation of taxa failes to prove their taxonomic independence, it may not be justified to take traditional taxa as being defined by discernible niches.

When we start with field study and work out the ecological data for a special unit of the biosphere which we call a niche we give a description of where to find an 
organism. In a second step of research we may provisionally give something like a warrant of arrest. Such characters are only for recognition, not for understanding. Understanding the organism, however, should be the final step in taxonomic research. It should include a list of capacities of the organism (its 'construction', its physiology or however we may call this). Understanding means the explanation of how the organism is qualified to live in the niche. Qualifications of this kind, so far, can be given for nearly a dozen Nostoc species. They will be published successively in forthcoming papers in the journal 'Senckenbergiana biologica' (Frankfurt am Main). (Autorreferat)

Address of the author: Dr. D. Mollenhauer, Forschungsinstitut Senckenberg, Aussenstelle Lochmühle, D-6465 Bieber, BRD.

Diskussion. Grundsätzliche Bemerkungen mehrerer Votanten machen bewusst, dass manche Grundprobleme der Cyanophytentaxonomie neu angegangen werden müssen. Übereinstimmend bestätigen sie, dass sich Nostoc-Arten nur bei Kenntnis ihrer Lebensgeschichte sicher bestimmen lassen. Mollenhauer untersucht seit langem die Entwicklungszyklen isolierter Nostoc-Klone in vitro. Nostoc pruniforme und $N$.zetterstettii sind durch ihn gut bekannt geworden. Die gemeinhin als $N$. muscorum bezeichnete Gruppe betrachtet er als äusserst schwierig. Die Frage Kanns: «Wie kann der praktisch arbeitende Ökologe ein Nostoc beim heutigen Stand der Forschung richtig bestimmen?» wird vom Spezialisten Mollenhauer mit «es ist kaum möglich» beantwortet. Golubić meint optimistischer, bei sorgfältiger Beobachtung könne man in vielen Fällen doch mit einiger Sicherheit bis auf das Artniveau bestimmen.

\subsection{Morphologie}

Hindák, F.: Morphological variability and taxonomy of some coccoid blue-green algae (Cyanophyta) [7]*

Three topics dealing with morphology and taxonomy of coccoid blue-green algae are discussed. In the first part the new records of some chroococcal algae are mentioned, then the problem of cell division in two markedly unequal portions is analyzed and, finally, a few examples of incrustation in planktonic chroococcal species are given. (Autorreferat)

Address of the author: Dr. F. Hindák, Ústav exper. biologie a ekologie SAV, Dúbravská cesta 26, 88534 Bratislava, CSSR.

Diskussion. Die von Hindák vorgestellten Typen regten zu grundsätzlichen Erörterungen über die Rolle und die Grenzen der Taxonomie im Bereich der Cyanophytenkunde an. Mollenhauer: Blossem Klassieren von Organismen kann man im Prinzip beliebige Kriterien wie Farbe, Grösse usw. zugrunde legen. Das ist aber noch nicht Taxonomie. Seriöse Taxonomie soll die wirkliche Ordnung im Bereich der Lebensformen zeigen und so zum Verständnis des Aufbaues der Organismenwelt führen. Golubić: In der Taxonomie liegt zudem ein kulturelles Anliegen: Sie soll nicht nur zum Verständnis der Natur führen, sondern auch zum gegenseitigen Verständnis unter den Biologen. Das erfordert Zurückhaltung bei Änderungen. Änderungen führen praktisch zu neuen nomenklatorischen Bezeichnungen für gleiche Formen oder zu gleichen Bezeichnungen für verschiedene Formen. Beides ist oft Quelle von Missverständnissen. So fassen Bourrelly, Geitler und Stanier-Waterbury die Gattung Dermocarpa nicht gleich auf. Wer den Begriff Dermocarpa braucht, muss genau sagen, welche der drei Auffassungen er ihm zugrunde legt. Komárek wirft das Problem der Hierarchie der Merkmale in die Diskussion: Die 
Ordnung der Merkmale nach ihrer Wichtigkeit ist oft schwer, erfordert sorgfältige Untersuchungen. Die Umschreibung von Familien, Gattungen und Arten setzt aber die Kenntnis und Anerkennung einer solchen Hierarchie voraus. Betrachtet man alle Merkmale als gleichwertig, bedeutet das praktisch den Schritt zur rein numerischen Taxonomie; eine hierarchische Gliederung in Familien, Gattungen, Arten wird illusorisch. Geht man aber in der Aufgliederung zu weit (wie etwa Bold bei Chlorococcus), wird jeder Stamm zu einer Art, die später niemand erkennen bzw. finden kann, weil sie eben nur in einem Stamm einer Kulturensammlung existiert.

Golubić, S.: The stalk producing habit in prokaryotic and eukaryotic unicells

The branched filamentous habit is common in attached cyanophytes and eukaryotic algae of freshwater and marine environments. This growth form has a selective advantage when algae compete for surface area and nutrients along the interface between the substrate and overlying water. Filamentous photosynthetic organisms require only a small settling area for holdfast attachment, while the metabolically active cells project into the water column above where they are exposed to a better nutrient supply by currents, and avoid shading. In contrast, metabolically active cells of competing attached unicells cover the substrate with a single layer or become crowded and mutually shaded. Some unicellular organisms have achieved an adaptation which makes them morphologically similar to branched cellular filaments. This morphology, which is achieved by the production of gelatinous (mostly polysaccharide) stalks, occurs in several groups of prokaryotic as well as eukaryotic unicells.

The simplest form of stalk is found in the coccoid cyanophyte Cyanostylon Geitler which accumulates by asymmetrical (basipetal) production of extracellular gelatinous envelopes elevating the cell from the substrate. In the course of cell division, the stalk branches, forming a little tree with the progeny cells located on the tips of the branches. A marine species of Cyanostylon copes in this fashion with high sedimentation rates of fine carbonate mud, thus keeping abreast of burial [1]. In the endolithic unicellular cyanophytes Solentia Ercegović and Hormathonema Ercegović the stalk production translocates the boring cells in the downward direction; they penetrate into the interior of carbonate substrates. The endoliths occupy a thin illuminated layer within the rock. In the unattached (planktonic) cyanophyte Gomphosphaeria Kützing, the radially arranged, dichotomously branched stalks keep the cells of a clonal colony in a single layer at the periphery of a sphere, in contact with the environmental water and nutrients. The tendency of nonphotosynthetic stalk-forming microorganisms to form radiating stellate colonies when settling on suspended particles has been noted by Hirsch [2].

The production of gelatinous stalks evolved independently in several groups of eukaryotic unicellular algae. The closest counterparts to Cyanostylon are the genera Chroothece Hansgirg of the bangiophycean rhodophytes, and Hormotila Borzi and Hormotilopsis Trainor et Bold which are tetrasporalean chlorophytes. These algae produce solid, layered gelatinous stalks. Oocardium Nägeli is a unique desmid, which produces hollow gelatinous tubes that immediately calcify and provide the algal cells with a mineral support similar to that of coral skeletons. Several types of 
gelatinous sleeves and stalks are produced by the freshwater diatom Gomphonema Agardh and the marine diatom Licmophora Agardh. Similar dichotomous stalks characterize the euglenophyte Colacium Ehrenberg. As is the case for some prokaryotic endoliths, gelatinous stalks convey the boring cells of the chlorophyte Gomontia caudata Setchell et Gardner into the interior of the carbonate substrate. The eukaryotic counterpart of the planktonic Gomphosphaeria is the chlorococcalean chlorophyte Dictyosphaerium Nägeli which commonly occurs in freshwater ponds. In the latter case, the cell wall structure of the parental cells is involved in the production of stalks similar to those of the attached marine chlorophyte Prasinocladus Kuckuck. It is apparent that the stalk building habit originated independently in these unrelated prokaryotic and eukaryotic algae by convergent evolution under similar selective pressure. (Autorreferat)

\section{REFERENCES}

1 Golubić, S.: Organisms that build stromatolites. In: Walter, M.R. (ed.): Stromatolites. Developments in Sedimentology, vol. 20, p. 113-126. Elsevier, Amsterdam-Oxford-New York 1976.

2 Hirsch, P.: Budding Bacteria. A. Rev. Microbiol. 28, 391-444 (1974).

Address of the author: Prof. Dr. S. Golubić, Dept. of Biology, Boston University, Boston, Mass. 02215, USA.

Diskussion. Offenbar sind viele der von Golubić besprochenen Formen verschiedener taxonomischer Stellung relativ schlecht bekannt, und die Bildung von Gallertstielen als evolutive Konvergenzerscheinung wurde bisher wenig untersucht. So werden besonders Fragen zu einzelnen Arten gestellt, zum Beispiel: Wie vollzieht sich die Propagation der Desmidiacee Oocardium? Golubić: Einzelne Zellen scheiden eine Gallerthülle aus und werden durch das Wasser verfrachtet. Golubić betrachtet das von ihm erwähnte marine Cyanostylon als bisher nicht beschriebene Art und verweist ferner auf das komplexe Zellteilungsprogramm von Hyella-Arten, welches wahrscheinlich eine Aufteilung in zwei Gattungen rechtfertigen würde.

\section{Campbell, S. E.: Morphological stability of fllamentous cyanophytes in Solar Lake (Sinai) and in culture}

The occurrence of benthic cyanophytes (cyanobacteria), the mats they build, as well as limnological features of the $5 \mathrm{~m}$ deep hypersaline Solar Lake were discussed by Cohen et al. [2-5]. Solar Lake is chemically stratified for much of the year with a temperature inversion in which the hypolimnion is hot and the epilimnion cooler. The lake was visited in July 1978 one week after the annual holomixis had begun. The thermocline was still present at about $3 \mathrm{~m}$ depth. Macromorphology of the mats observed by skin diving was similar to the descriptions cited above. Representative samples from each mat type were taken for microscopy live, inoculation of mixed cultures and fixed with $3 \%$ formalin or $2.5 \%$ glutaraldehyde in environmental water for later study. (After 1 $1 \frac{1}{2}$ years samples fixed with glutaraldehyde disintegrated; formalin fixed samples retained their morphological integrity.) Modified Pfennig's medium (Cohen, personal communication 1978) designated here as ssolar lake medium (SLM)' was used for culturing. 
The flat shallow water mat (near the surface) was dominated by Microcoleus chthonoplastes. Oscillatoria salina and an Aphanothece sp. (similar to the A. halophytica cultured by Cohen) were present in small numbers. M.chthonoplastes was isolated on SLM $90 \%\left(\mathrm{NaNO}_{3}\right.$ substituted for $\left.\mathrm{NH}_{4} \mathrm{Cl}\right)$ as a single filament containing several trichomes. In culture as in nature trichomes bundle within a common sheath, and cell morphology and morphometry is the same. Oscillatoria salina and Spirulina subsalsa have each been brought into clonal culture by streaking on solid agar and micromanipulated transfer of a single trichome into liquid medium. In nature, O. salina was found only in the shallow water mat, but it was isolated from the original mixed culture of the deepest flocculose mat $(4 \mathrm{~m})$ in which only organisms resembling Oscillatoria limnetica were seen in fresh and fixed field samples. A similar situation exists for $S$. subsalsa which was isolated from the shallow water mat but has been found in the field only in the yellow pinnacle mat $(2 \mathrm{~m})$ in which a large Aphanothece sp. (4-5 $\mu \mathrm{m}$ wide, $5.25-12.5 \mu \mathrm{m}$ long cells) dominates that has not grown as yet in any culture. The Aphanothece sp. is accompanied by a small $(1 \mu \mathrm{m}$ diameter) Phormidium sp. which has a distinctive morphology. In the field and in mixed culture it has $4.5-10.0 \mu \mathrm{m}$ long cells which are not constricted at the cross walls but have one gas vacuole on each side of the septum and a larger gas vacuole at the tip of the slightly capitate endcell. The Phormidium provides architectural support for the pinnacles and may be responsible for their genesis. These findings underscore the fallacy that growth in culture can be used in lieu of field identifications to represent the current status of organismal dominance and distribution in the natural environment. It is also important to note that $M$. chthonoplastes, O. salina, S. subsalsa, and the small Phormidium sp. described above are morphologically identical to their formalin-fixed naturally occurring counterparts. This is a strong testament to the stability of morphology in these taxa.

The isolate called Oscillatoria limnetica has been shown by Cohen et al. [1] and Oren and Shilo [6] to be metabolically unique among cyanophytes: in addition to the usual green plant type photosynthesis (using photosystems I and II) and aerobic respiration under oxygenated conditions, when this culture is grown anaerobically it is capable of photosynthesis using photosystem I alone (like purple and green photosynthetic bacteria), can ferment polyglucose to lactate and $\mathrm{CO}_{2}$, and respire using sulfur as the electron acceptor. The isolate was obtained from three separate sources (all of which ultimately originate from the Cohen isolate): Y. Cohen grew the isolate in SLM containing sterile-filtered Solar Lake water; M. Shilo grew it in SLM made with artificial seawater; R. Rippka grew it in a concentrated artificial seawater medium. Despite the differing media, morphometry and morphology was uniform for all three cultures. Trichomes had straight-sided cells with cross walls only slightly or not at all constricted. Cell width (inclusive for all three cultures) was $2.05 \pm 0.28 \mu \mathrm{m}, \mathrm{n}=40$, with a range of $1.75-2.5 \mu \mathrm{m}$ and each trichome examined maintained the same diameter throughout its length. Cells measured $6.99 \pm 1.87 \mu \mathrm{m}$, $\mathrm{n}=40$ in length with a range of $4.0-11.5 \mu \mathrm{m}$ (cells longer than wide).

The naturally occurring $O$. limnetica morphotype population was statistically evaluated using a random sample of $n=132$ cells (of 132 formalin fixed trichomes) from three different mat types (2, 3 and $4 \mathrm{~m}$ depths). The data are shown graphically in the figure. Trichome width for the total sample is $2.31 \pm 0.65 \mu \mathrm{m}$. (Solid line repre- 
sents one standard deviation, dotted line two.) Trichomes that are wider than $3.61 \mu \mathrm{m}$ lie outside of two standard deviations, and the frequency histogram is skewed to the right with a secondary mode at $4.0 \mu \mathrm{m}$. The sample was then redefined and split to exclude trichomes wider than $3.25 \mu \mathrm{m}$. The resulting population 1 has cell width of $2.23 \pm 0.53 \mu \mathrm{m}$, range $1.25-3.25 \mu \mathrm{m}$ and cell length range of 3.25$11.0 \mu \mathrm{m}$. Population 2 cell width is $4.0 \pm 0.25 \mu \mathrm{m}$, the range is $3.5-4.5 \mu \mathrm{m}$, and the cell length range is $3.75-10.5 \mu \mathrm{m}$. Population 1 remains, however, a skewed distribution, having a shoulder at $3.0 \mu \mathrm{m}$. It is probably composed of two subpopulations each having a normal Gaussian distribution, but a much larger sample size (n) would be necessary to define them. The three modes which fall at 2.0,3.0 and $4.0 \mu \mathrm{m}$ indicate the presence of three size classes within the O.limnetica morphotype.

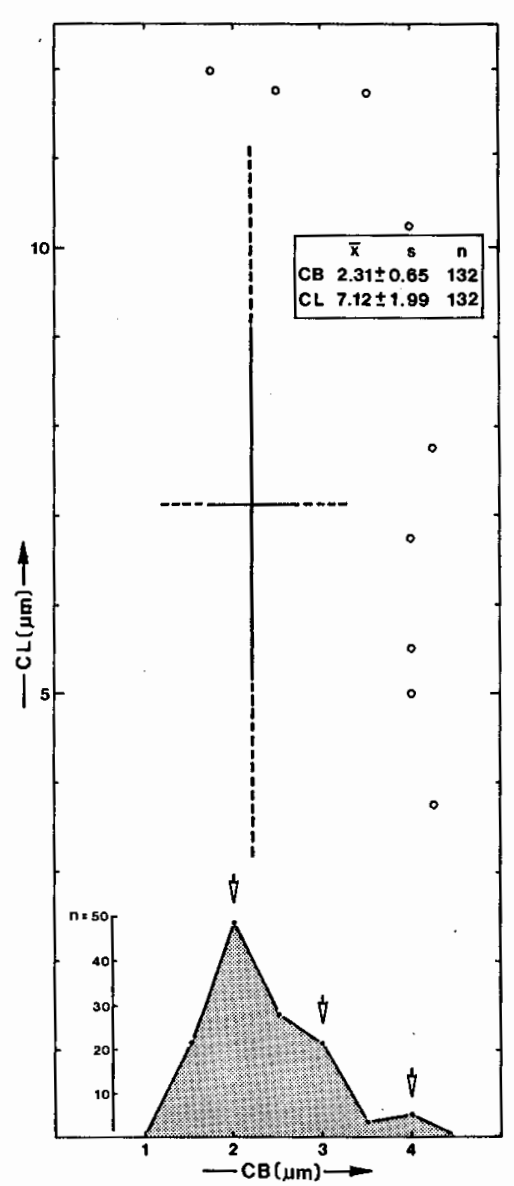

Morphometric data for the naturally occurring Oscillatoria limnetica morphotype: cell breadth (CB) and cell length (CL) mean ( $X)$ and standard deviation (s) are shown by the cross (one $s=$ bold line, two $s=$ dotted line). Measurements falling outside two $s$ are identified by circles. The frequency histogram shows the distribution of cell widths (CB). Modes are identified by arrows. 
Attempts to achieve single trichome isolates of each of the proposed size classes from original mixed cultures are in progress.

In naturally occurring mats, all size classes of the $O$. limnetica morphotype produce sheaths characteristic of the genus Phormidium. Trichomes with single sheaths are commonly found in flat cohesive mats that occur in a zone intersected by the thermocline $(3 \mathrm{~m})$, but the sheaths are rarely seen in the deep flocculose mat $(4 \mathrm{~m})$ indicating that under the prevailing conditions there trichomes are either highly motile (as they are in culture), regularly abandoning the sheaths they produce, or producing them only intermittently. Sheath production occurs in culture as well, although not consistently.

The salinity tolerance of the mixed community of the deep flocculose mat $(4 \mathrm{~m})$ and the thermocline transition mat $(3 \mathrm{~m})$ has been tested using a range of salinities that occur in the lake (see Cohen et al. [2]). On solid agar at an average temperature of $22{ }^{\circ} \mathrm{C}$ growth occurred at $181 \%, 146 \%$, was optimal at $90 \%$, was poor at $54 \%$, and no growth was visually observable at $46 \%$. These results compare well with those of Cohen (personal communication, 1978) who measured the salinity tolerance of the O. limnetica isolate using liquid Chu 11 medium $+\mathrm{NaCl}$, at temperatures of $15^{\circ}$, $35^{\circ}$, and $50^{\circ} \mathrm{C}$ monitored by Lowry protein determinations. It is possible that with very careful and gradual downward shifts in salinity the organisms might adapt to growth at lower levels, however it is concluded that the identification of the Cohen culture as Oscillatoria limnetica is in error as the entire community is incapable of significant growth in marine, much less freshwater salinities $(O$. limnetica Lemmerman is a freshwater organism). In addition, the presence of firm single sheaths in nature as well as culture precludes identification in the genus Oscillatoria. It is suggested that a new taxon be formally described to include morphological, metabolic, and ecological data. It remains to be established, however, whether the three size classes naturally occurring in Solar Lake represent the variability of a single taxon, several strains of a single metabolically defined species, or metabolically as well as morphometrically differing species. (Autorreferat)

\section{REFERENCES}

1 Cohen, Y., Padan, E., and Shilo, M.: Facultative anoxygenic photosynthesis in the cyanobacterium Oscillatoria limnetica. J. Bact. 123 (3), 855-861 (1975).

2 Cohen, Y., Krumbein, W.E., Goldberg, M., and Shilo, M.: Solar Lake (Sinai). 1. Physical and chemical limnology. Limnol. Oceanogr. 22, 597-608 (1977a).

3 Cohen, Y., Krumbein, W.E., and Shilo, M.: Solar Lake (Sinai). 2. Distribution of photosynthetic microorganisms and primary production. Limnol. Oceanogr. 22, 609-620 (1977b).

4 Cohen, Y., Krumbein, W.E., and Shilo, M.: Solar Lake (Sinai). 3. Bacterial distribution and production. Limnol. Oceanogr. 22, 621-634 (1977c).

5 Cohen, Y., Krumbein, W.E., and Shilo, M.: Solar Lake (Sinai). 4. Stromatolitic cyanobacterial mats. Limnol. Oceanogr. 22, 635-656 (1977d).

6 Oren, A., and Shilo, M.: Anaerobic heterotrophic dark metabolism in the cyanobacterium Oscillatoria limnetica: sulfur respiration and lactate fermentation. Arch. Microbiol. 122, 77-84 (1979).

Address of the author: Susan E. Campbell, Dept. of Biology, Boston University, Boston, Mass. 02215, USA. 
Diskussion. Die weitgehende morphologische Übereinstimmung zwischen Natur- und Kulturmaterial der von Campbell besprochenen Oscillatoriaceen wird besonders hervorgehoben. Im übrigen steht die aus dem Solar Lake isolierte Oscillatoria limnetica (=Phormidium sp.?) im Zentrum der Diskussion. Chang: Kann Ihre O. limnetica anaerob leben? Campbell: Darüber fehlen bisher exakte Untersuchungen. Hickel fand einmal in Brackwasser eine Oscillatoria, die wie O.limnetica aussah, bezweifelt aber die Identität mit der von Lemmermann aus Süsswasser beschriebenen Form. Allgemein wird die taxonomische Übereinstimmung der im Solar Lake vorkommenden Art mit Oscillatoria limnetica Lemmermann für ausgeschlossen gehalten. Doch sind vorerst weitere experimentelle Arbeiten notwendig. Eigentlich sollte man O.limnetica Lemmermann am Locus classicus - sofern er überhaupt feststellbar ist und die Art dort noch vorkommt - sammeln, kultivieren und experimentell mit der Form aus dem Solar Lake vergleichen.

\section{Chang, T.-P.: Morphologie von Gloeotrichia echinulata (Smith) Richter in axenischer Kultur}

Die morphologische Struktur von G. echinulata wurde zum ersten Mal in axenischer Kultur untersucht und dabei festgestellt, dass diese Alge keine kugelförmigen Kolonien bildet, sondern in vielfältigen Entwicklungsformen auftritt (Abb.). Es

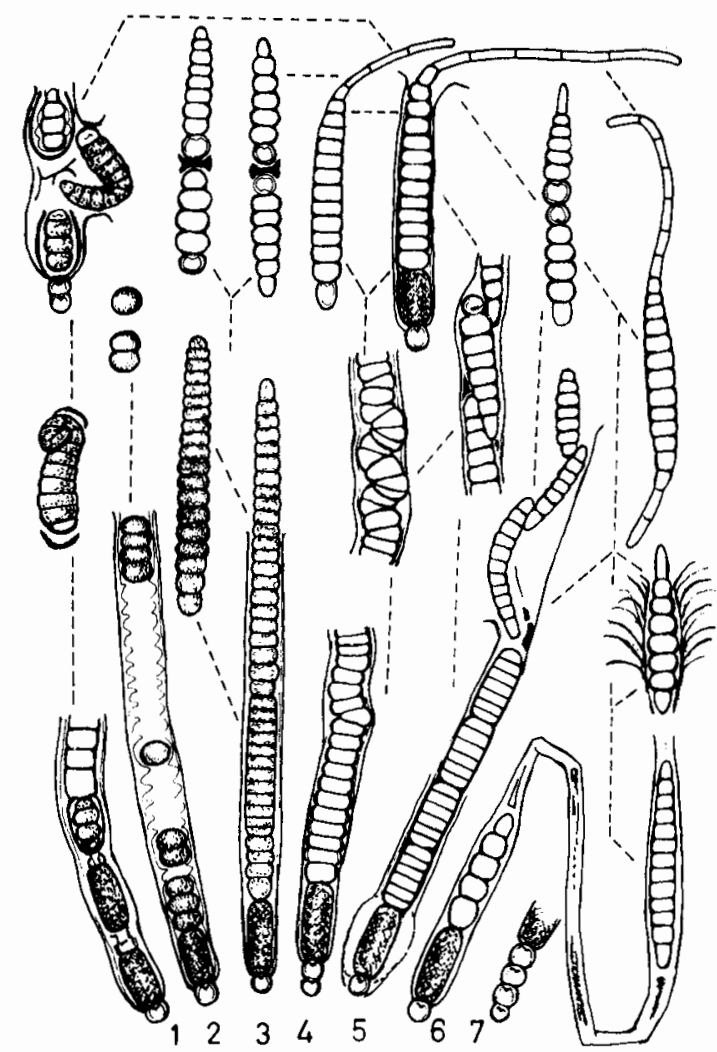

Schematische Darstellung des Lebenszyklus von Gloeotrichia echinulata (Smith) Richter (Sporendurchmesser etwa $10 \mu \mathrm{m}$ ). 1: Sporenkeimung. 2: Produktion der Exosporen. 3: Hormogenesebewegliche Hormogonien. 4: «Stauchungs»-Wachstum. 5: Fragmentierung zur Hormogonienbildung unbewegliche Hormogonien. 6: Bildung der Hormozysten. 7: Keimung der Heterozysten (nicht beobachtet). 
wurde beobachtet, dass sich aus dem Meristem bewegliche Hormogonien entwikkeln, die dann weiter zum Rivularia- und Gloeotrichiazustand auswachsen. Durch Zugabe organischer Substanzen in Nährlösungen liess sich eine meristematische «Stauchung» der Trichome beobachten, aus der später neue Trichome auswuchsen (in 10-100facher Vielfalt). In nährstoffarmen Medien traten unbewegliche Hormogonien bzw. Hormozysten auf. Die Alge verliert nicht die Fähigkeit zur Bildung sekundärer Zellen, deren Entstehung deutlich von Kulturbedingungen abhängig ist. Die Haarzellen erschienen vor den Dauerzellen und Heterozysten und wurden nach einer gewissen Zeit abgestossen. Die letzteren kamen basal oftmals kettenförmig vor, jedoch liess sich ihre Bildung durch organische Substanzen verhindern. Die Morphologie der Alge in stickstoffhaltigen Nährlösungen ist vielfältig: Bei Anwesenheit von Nitrat sind die Formen ziemlich normal im Gloeotrichiazustand; dagegen fördert Ammonium die Bildung der Rivularia- bzw. Homoeothrix-ähnlichen Formen. Die Keimung von Dauerzellen wurde beobachtet, jedoch nicht die der Heterozysten. Die systematische Stellung dieser Alge wird anhand der obenerwähnten Ergebnisse erneut diskutiert und mit denen der Literatur verglichen. Eine Detailarbeit darüber wird in «Nova Hedwigia» erscheinen. (Autorreferat)

Adresse des Autors: Dr. T.P. Chang, Institut für Strahlenhygiene, Bundesgesundheitsamt, D-8042 Neuherberg, BRD.

Diskussion. Golubić: Gloeotrichia und Rivularia sind sicher unterscheidbare Gattungen: Gloeotrichia bildet Dauerzellen und tritt nur in stehenden Gewässern auf, während Rivularia keine Dauerzellen bildet und auch in Fliesswasser vorkommt. So wird Gloeotrichia in der Arbeit Kanns über die Algen österreichischer Bergbäche [9]* nicht erwähnt. Komárek: Innerhalb der Gattung Gloeotrichia lassen sich in der Natur die Arten G.echinulata, G. Pisum und G. natans sowohl morphologisch als ökologisch klar unterscheiden. Die Frage der Koloniebildung wird eingehend besprochen: Chang konnte in Kulturen die für G. echinulata typischen kugeligen Kolonien mit radial angeordneten, weit über die kompakte Kugel hinausragenden haarartigen Trichomen nicht erzeugen. Cronberg: Diese Kugelkolonien sind in der Natur sehr stabil und lassen sich sogar an subfossilen Algen nachweisen. Mollenhauer: Es ist denkbar, dass Virusinfektionen in Kulturen gestaltverändernd die Bildung von Kolonien beeinflussen. Lewin: Der Einsatz von Schüttelkulturen könnte sich lohnen. So bildet Cladophora in solchen klumpige Aggregate. Stanier erkundigt sich, wie die Alge axenisch gemacht wurde. Chang: Hormogonien und Dauersporen wurden gewaschen. Stanier: Auf der niedrigen Differenzierungsstufe von Hormogonien lassen sich Cyanophyten nicht sicher identifizieren. So bleibt - auch angesichts des Fehlens von Gasvakuolen in manchen der abgebildeten Trichome - ein gewisser Zweifel, ob wirklich eine Gloeotrichia-echinulata-Kultur vorliegt. Komárek: Da ist freilich zu beachten, dass viele Algen in der Natur in ihrer ökologischen Nische eine geringe, in der Kultur aber, wo die Konkurrenz anderer Arten fehlt, eine weite Variabilität zeigen. So ist denkbar, dass ein Klon in der Natur regelmässig Gasvakuolen besitzt, während diese in der Kultur je nach Bedingungen auftreten oder fehlen können.

Jeeji Bai, N., and Seshadri, C.V.: On coiling and uncoiling of trichomes in the genus Spirulina

Three distinct morphological variants have been recognized and described in a local isolate of Spirulina fusiformis: the S-type variant with trichomes having more or less regular and distant coils, the $\mathrm{C}$-type variant with trichomes having a distinct spindle shape with close coils and the H-type variant with trichomes forming a dumb-bell 
shape with very close to tight coils. Physicochemical conditions have been established in the laboratory and mass-scale experiments, in which the different variants are formed. In view of the observed morphological variability, the taxonomic position of the alga is discussed. (Autorreferat)

Address of the authors: Dr. Nagaraj Jeeji Bai, C.V. Seshadri, Institute for Advanced Studies in Botany, University of Madras, Madras 600005 , India.

Diskussion. Obwohl die Autorin die Weite der Windungen von Spirulina-Trichomen als ökologisch bedingt und nicht als taxonomisches Merkmal betrachtet, möchten einige Votanten die Frage noch offenlassen: Sie vermissen den exakten Nachweis, dass die Kulturen, mit denen experimentiert wurde, sichere Klone waren, das heisst aus je einem einzigen isolierten Faden herangezogen wurden. Golubić hat den Eindruck, die Ausbildung der Windungen hänge mit der Verteilung der Zellteilungszonen zusammen. Das würde bedeuten, dass Spirulina als vielzelliger Organismus funktionieren würde, indem über die Länge der Trichome hinweg distinkte meristematische Zonen aufträten.

Meffert, M.-E., Oberhäuser, R., and Overbeck, J.: On apices, trichome breakage and fine structure of cell envelopes in Oscillatoria redekei

The fine structure of Oscillatoria redekei van Goor, especially that of the cell envelopes was investigated by transmission electron microscopy, the apices and the trans- and intercellular trichome breakage by light microscopy and scanning electron microscopy. The end cells of the trichomes of $O$. redekei are polymorph. Besides rounded apices with roundish gas vacuoles there also occur tapered and long pointed apices with correspondingly formed gas vacuoles.

Transcellular trichome breakage of living cells are described as well as the occurrence of intercellular trichome breakage and its development on certain parts of the trichome by intercellular constrictions with tapering of the adjacent cells and their gas vacuoles. In ultrathin sections the longitudinal walls show the cytoplasmic membrane, the $\mathrm{L}_{1^{-}}, \mathrm{L}_{2^{-}}-\mathrm{L}_{3^{-}}$and $\mathrm{L}_{4}$-layer with centripetal inflections on the cross wall. The $\mathrm{L}_{4}$-layer seems to be unstructured and a sheath or slime layer are not observable. The cross wall and the septum formation show the cytoplasmic and the $\mathrm{L}_{1}$-layers twice - on both sides - whereas the $\mathrm{L}_{2}$-layers seem to be only one layer without a middle lamella in the contrary e.g. to O.rubescens. - Therefore the fine structure of cell envelopes and the mode of trichome breakage differ in Oscillatoria species. (Autorreferat)

Address of the authors: Dr. M.-E. Meffert, Dr. R. Oberhäuser, Dr. J. Overbeck, Max-Planck-Institute of Limnology, D-232 Plön/Holstein, BRD.

Diskussion. Rippka fand bei acht Pseudanabaena-Arten die gleiche Feinstruktur der Zellwände, wie sie nun für Oscillatoria redekei dargestellt wurde. Sollten Oscillatoria und Pseudanabaena evtl. zusammengelegt werden? Stanier möchte - bevor Untersuchungen an weiteren Arten vorliegen - vorerst nur O. redekei zu Pseudanabaena stellen. Meffert ergänzt, dass sich zudem Phormidium einzig durch die Scheidenbildung von Pseudanabaena unterscheidet. Die Aufgliederung des Komplexes OscillatoriaPseudanabaena-Phormidium ist eine schwierige Zukunftsaufgabe. Stanier betrachtet aufgrund der DNABasen-Zusammensetzung Pseudanabaena als eine Gattung von äusserster Diversität. Golubić erwähnt schliesslich, die Gattung Pseudanabaena sei lange vernachlässigt und erst von Anagnostidis wieder in 
ihrer Bedeutung erkannt worden. Ein Grund der zeitweiligen Vernachlässigung mag nach Komárek und Mollenhauer in der Kürze mancher Originaldiagnosen liegen. Dabei erweisen sich diese bei genauer Lektüre oft als weit besser als zuerst angenommen. So müssen sie oft in ihrem Gehalt nicht geändert, wohl aber ausgeweitet und ergänzt werden. Unentbehrlich sind in vielen Fällen ergänzende Zeichnungen.

\section{4 Ökologie}

Hindák, F.: Blue-green algal flora from the thermal springs at Piešt'any and Sklené Teplice Spa in Slovakia

In the paper the results of the investigation of thermophilic blue-green algae of two known spas in Slovakia, Piešt'any and Sklené Teplice, are presented. An earlier contribution on the coccoid blue-green algae, presented at the 7th Symposium of the IAC at Lednice, Czechoslovakia, in 1976, has been published [2]. Both studied localities have thermal water of a similar composition (sulphuric gypsum) but they differ with respect to other properties. Whereas at Sklené Teplice the thermal springs (the main Joseph well has a temperature of $52.3^{\circ} \mathrm{C}$ ) form travertine cascades in the open air, thermal water at Piešt'any from the main Trajan well (the original temperature is $67^{\circ} \mathrm{C}$ ) is captured beneath the surface and conducted into a collector thence to be distributed also in two open concrete maturing basins filled with mud from the nearby dead arm of the Váh river. The mud is continuously overflowed by the layer of $30-50 \mathrm{~cm}$ of thermal water in which a rich biomass of blue-green algae is developing (see also [2, 4]). Blue-green algae were studied immediately after sampling, then in laboratory subcultures and pure biphasic cultures. The study is complicated by the fact that apart from obligatorily thermophilic algae, some apparently nonthermophilic species also occur there, especially in places where temperature is essentially lower than in springs. In some cases the identification of the species is difficult because of wide variability in the morphologies of pseudofilaments, filaments, branching of filaments, etc. Sampling was not regular and observations from the winter period are missing, so the given list of species cannot be complete. Therefore, the results presented here have to be considered partial and preliminary.

In the investigated thermal localities filamentous blue-green algae are dominant, coccoid species occur sporadically or only rarely dominate. In maturing basins at Piešt'any three filamentous algae form practically the whole algal biomass: Oscillatoria princeps, Phormidium cf. ambiguum and Phormidium sp. with filaments 1.5-2 $\mu \mathrm{m}$ wide. From among coccoid species there occur Cyanothece minervae, Aphanothece bullosa, Chroococcidiopsis thermalis, Chroococcus globosus, Synechococcus elongatus, Gloeocapsa sp. The number of filamentous blue-green algal species at Sklené Teplice exceeds that at Piešt'any. On the travertine cascades dominate Phormidium cf. ambiguum with filaments 5-7.5 $\mu \mathrm{m}$ wide, Mastigocladus laminosus (= Hapalosiphon fontinalis) mostly as unbranched filaments $3-4 \mu \mathrm{m}$ wide and with regular cylindrical cells, and Lyngbya/Phormidium sp. with filaments around $2 \mu \mathrm{m}$ wide. Apart from these species there frequently occur coccoid species: Chroococcidiopsis thermalis, Siphononema thermophila and species of the genera Synechocystis and Gloeocapsa. 
Preliminary list of species found in Pieš'tany (P) and Sklené Teplice (ST):

Coccoid blue-green algae: Aphanothece bullosa (Menegh.) Rabenh. (ST), A.thermicola Hind. (ST), Chroococcidiopsis thermalis Geitl. f. (P, ST), Chroococcus globosus (Elenk.) Hind. (P), Chroococcus sp. (ST), Cyanothece minervae f. (Cop.) Kom. (P), Cyanothece sp. div. (P, ST), Gloeocapsa cf. bituminosa (Bory) Kütz. (P), G. cf. montana Kütz. (P, ST), Myxosarcina thermalis Hind. (P), Siphononema thermophila Hind. (ST), Synechococcus cf. elongatus Näg. (P), S. cf. minimus (Lemm.) Kom. (ST), Synechococcus sp. div. (P, ST), Synechocystis cf. crassa Vor. var. major Geitl. (ST), Synechocystis sp. (ST).

Filamentous blue-green algae: Anabaena sp. (P), Calothrix cf. fusca Born. et Flah. (ST), Cylindrospermum sp. (ST), Lyngbya epiphytica Hier. (ST), Lyngbya sp. div. (P, ST), Mastigocladus laminosus Cohn (= Hapalosiphon fontinalis (Ag.) Born.) (P, ST), Microcoleus steenstrupii Boye-Pet. (ST), Nostoc sp. (? Chlorogloeopsis fritschii Mitra et Pandey) (ST), Plectonema sp. div. (ST), Oscillatoria cf. acutissima Kuff. (ST), O. princeps Vauch. (P), O. cf. tenuis Ag. (ST), O. cf. splendida Grev. (ST), Phormidium cf. ambiguum Gom. (P, ST), Ph. cf. corium (Ag.) Gom (P), Ph. cf. tenue (ST), Phormidium sp. div. (P, ST), Scytonema sp. (ST), Spirulina maior Kütz. (ST). (Autorreferat)

\section{REFERENCES}

1 Copeland, J.J.: Yellowstone thermal Myxophyceae. Ann. N.Y. Acad. Sci. 36, 1-232 (1936).

2 Hindák, F.: Coccal blue-green algae from the thermal springs at Piešt'any and Sklené Teplice Spa in Slovakia. Arch. Hydrobiol., Suppl. 51, Algol. Stud. 21, 359-376 (1978).

3 Komárek, J.: Taxonomic review of the genera Synechocystis Sauv. 1892, Synechococcus Näg. 1849, and Cyanothece gen. nov. (Cyanophyceae). Arch. Protistenk. 118, 119-179 (1976).

4 Reháková, Z.: Diatoms from thermal waters and mud in Piešt'any Spa (Slovakia). Arch. Hydrobiol., Suppl.49, Algol. Studies 15, 141-175 (1976).

Address of the author: Dr. F. Hindák, Ústav exper. biologie a ekologie SAV, Dúbravská cesta 26, 88534 Bratislava, CSSR.

Diskussion. Sie dreht sich vorerst um Fragen der Temperatur: Die Mikrostandorte, an denen Untersuchungsmaterial gesammelt wurde, weisen Temperaturen zwischen etwa 25 und $62^{\circ} \mathrm{C}$ auf (Piešt'any: Quelle: $67^{\circ} \mathrm{C}$, Reifungsbecken: $35-62^{\circ} \mathrm{C}$, Sklené Teplice: Josephsquelle $52^{\circ} \mathrm{C}$, Travertinkaskaden in der Mitte $49^{\circ} \mathrm{C}$, am Rande $25-30^{\circ} \mathrm{C}$ ). Hindák kultiviert alle Formen bei $25-30^{\circ} \mathrm{C}$. Die umfangreiche Artenliste besteht also nicht aus einer Auswahl thermophiler Cyanophyten sensu Castenholz. Sodann werden Probleme der Bestimmung von Natur- und Kulturmaterial erörtert. Hindák studierte die Proben unmittelbar nach dem Sammeln und legte dann Kulturen an. Mollenhauer: Gab es Fälle, in denen die Bestimmung von Naturmaterialien aufgrund von Kulturen revidiert werden musste? Hindák: Manche Formen waren als Natur- wie als Kulturmaterial leicht zu bestimmen, andere, z.B. Mastigocladus laminosus, waren nur in Kulturen sicher bestimmbar. Golubić regt an, bei Abbildungen immer zu vermerken, ob Natur- oder Kulturmaterial als Vorlage diente.

Campbell, S. E.: Cyanophyte associations in the benthos of two marine ponds Two experimental ponds of the Mariculture Laboratory at Eilat, Israel, have been studied for one year to determine changes in the dominance and association of 
species of marine cyanophytes which build extensive benthic mats. One pond, which was designated the 'control pond' is maintained with a constant flow of water pumped from the Red Sea. The other pond is identical in all respects except that it has a fish stock which is fed a commercial fish food on a regime of overfeeding.

The control pond cyanophyte flora is very diverse and species dominance shifts virtually every month. However, one trend was established, coccoid genera dominated heavily during the summer and fall, while filamentous taxa produced most of the winter biomass. It is not yet clear whether these developments represent truely seasonal changes. During the same period of time the benthic cyanophyte population of the fish pond remained unialgal (Oscillatoria Bonnemaisonii). Thus, the (relatively) 'nutrient poor' control pond showed frequent changes and a high diversity of cyanophyte species while the benthos of the heavily eutrophied fish pond remained constant. The presence of fish and an overload in nutrients is accompanied by a decrease in cyanophyte diversity. (Autorreferat)

Address of the author: Susan E. Campbell, Dept. of Biology, Boston University, Boston, Mass. 02215, USA.

Diskussion. Kann weist vorerst auf Friedrichs Untersuchungen über jahreszeitliche Schwankungen der Zusammensetzung der Algenbiozönose in der Erft hin [4]*. Im oberen Teil mit normalem Temperaturverlauf bedingt dieser weitgehend die Entwicklung der Vegetation. Unterhalb einer Warmwassereinleitung, wo das Flusswasser immer warm bleibt, ist das Licht der bestimmende Faktor. - Golubić: Der entscheidende Faktor im einen Teich Campbells dürfte das Übermass an Fischfutter sein. Cronberg: Beim Vergleich der Vegetation von Fischteichen mit der fischloser Teiche muss die Beweidung durch die Fische sorgfältig beachtet werden. Kann legt Ergebnisse ihres 16 Jahre dauernden Studiums von 10 alpinen Bächen dar [9]* und zeigt die grundlegend verschiedenen Verhältnisse gegenüber Teichen. So kann bei einem einzigen Hochwasser eines Bergbaches praktisch der gesamte Algenbewuchs der Steine durch Geröll weggescheuert werden. Bürgi: Ob eine Alge in einem Gewässer wächst, hängt sehr wenig mit ihren physiologischen Bedürfnissen zusammen; die ökologische Situation ist viel entscheidender.

\section{Komárková, J.: Factors influencing the development of Aphanizomenon flos-aquae}

bloom in Czechoslovak eutrophic fish ponds

Choking of inland waters by the water blooms of blue-green algae is a threat whenever pollution such as human wastes, or agricultural fertilizers enter the watershed. Sometimes the monospecific population of a water bloom can grow so much that several thousands of filaments or several million cells per $\mathrm{ml}$ occur. The chlorophyll a concentration may reach hundreds of $\mu \mathrm{g}$ per 1 . The usual $\mathrm{pH}$ values are 9-10 revealing, that gaseous $\mathrm{CO}_{2}$ supply is exhausted. However, carbonate from the buffer system may supply enough carbon to maintain an abundant water bloom. Warmer weather may result in population collapse. The outcome of the ensuing decomposition of dead algae is rapid depletion of dissolved oxygen to the concentrations dangerous for fish.

The occurrence of blooms of Aphanizomenon flos-aquae or Anabaena is undesirable in the ponds also because of the large dimensions of filaments, what prevents the Crustaceoplankton (which represents a higher trophic level in the pond) to utilize it for food. 
During the past few years we have studied the occurrence of Aphanizomenon in a fish-pond system in Třebon̆, Czechoslovakia. Hrbáček [2] mentioned that blooms of Aphanizomenon are more frequent in ponds in comparison with other water bodies. The reason is the fertilization of ponds with superphosphate, manure, lime and limestone. Boyd [1] summarized the knowledge about the phosphorus dynamics in ponds and stated that 'too much phosphorus is sometimes responsible for excessive production of blue-green algae'. Unlike green algae, which are dependent on the nitrogen present, blue-green algae such as Aphanizomenon can provide a great part of their own nitrogen requirement by fixing atmospheric nitrogen: this may benefit them in the competition with other algae. Another factor, which affects the competitive outcome of blue-green vs green algae is their low irradiance requirement. Several authors [3] e.g. have shown that blue-greens prefer lower irradiance for maximum growth than do the green algae. Thus, it is supposed that at the end of spring, the first Aphanizomenon filaments"develop at the bottom during the spring maximum of phytoplankton, and are then spread throughout the water column by wind induced turbulence.

In the pond of Třebon̆, the Aphanizomenon blooms are dependent on yet another factor connected with the fish-pond management (see also [2]). We have found that

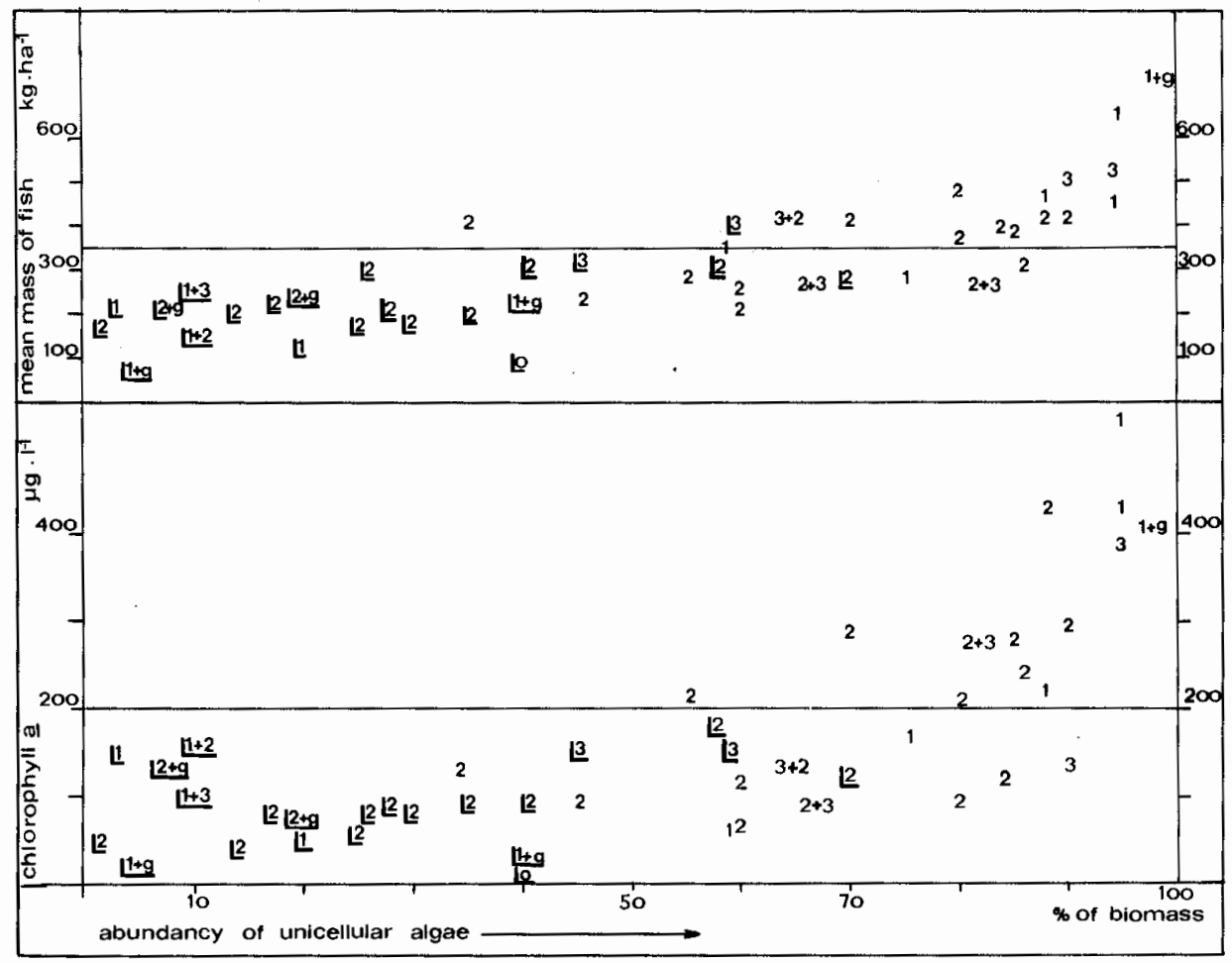

Figure 1. Results of the seasonal sampling of 46 ponds in the Treboñ basin in 1978. (Mean mass of fish is the average between the initial and final fish stocks in one year.) 


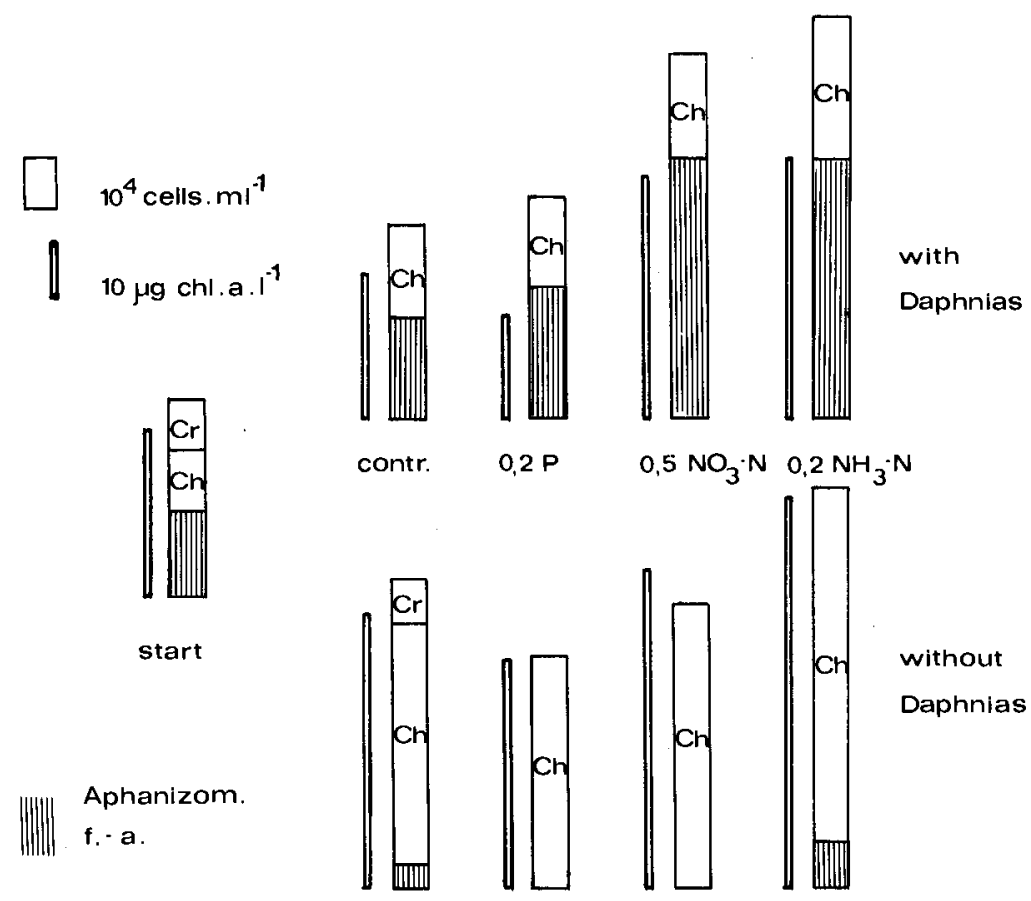

Figure 2. Experiment performed in plastic bags in pond water.

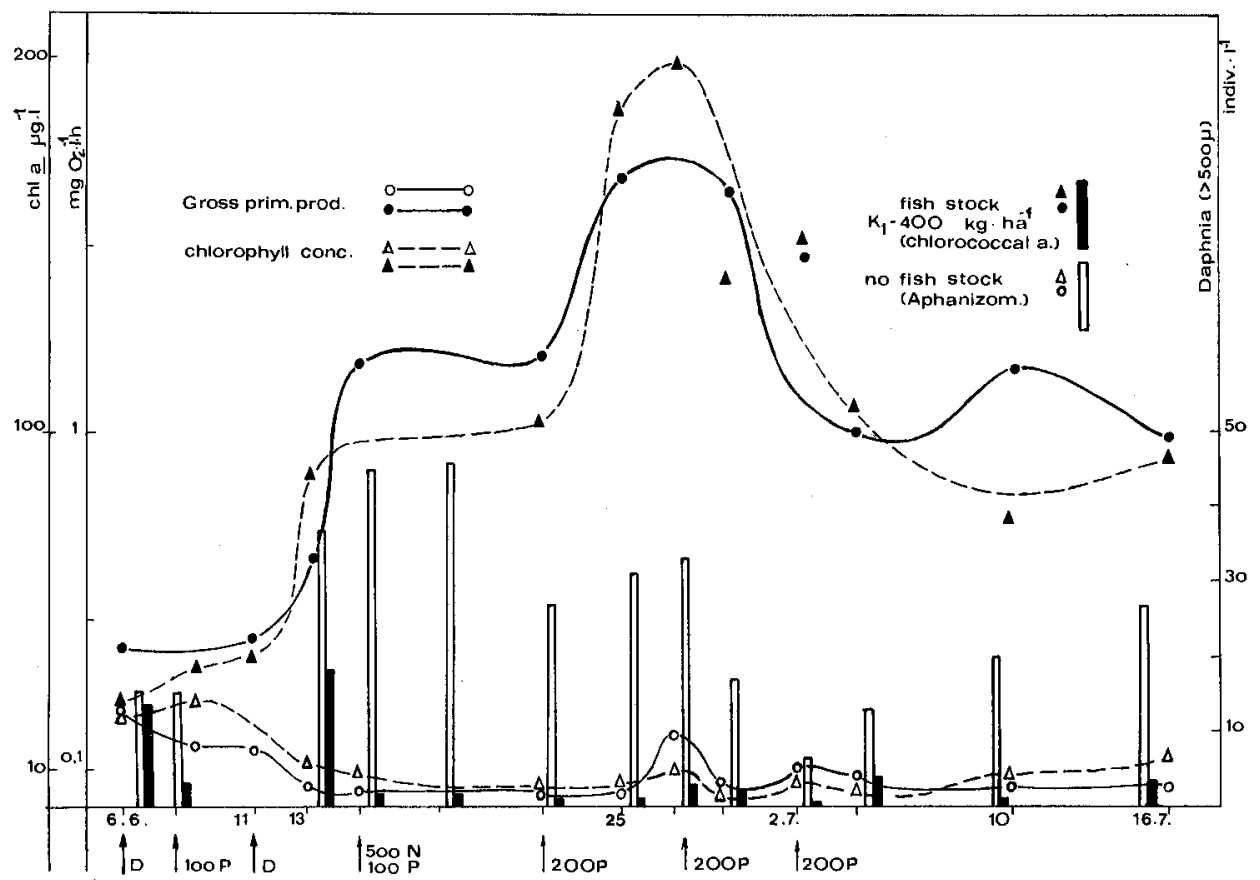

Figure 3. Difference between two pairs of experimental pools made of plastic (no fish in one pair, very high stock in the other). 
Aphanizomenon blooms can be expected to occur, when the ponds are stocked with number of fish corresponding to the mean seasonal total mass of fish up to $350 \mathrm{~kg} \cdot \mathrm{ha}^{-1}$ (fig. 1). As shown, we did not find any difference due to age of the stocked fish (carp 1,2 and 3 years old and the generic carp), it is only the mass of fish per ha that seems to be important. However, the unialgal population of Aphanizomenon appears very often in ponds stocked with 1-year-old carp (mean weight $7 \mathrm{~g})$.

The bloom of Aphanizomenon starts at the end of May. If the pond is properly stocked, the fish, when growing, reach a critical high mass and the Aphanizomenon is replaced by a mixture of green algae and Microcystis, because the fish predation is

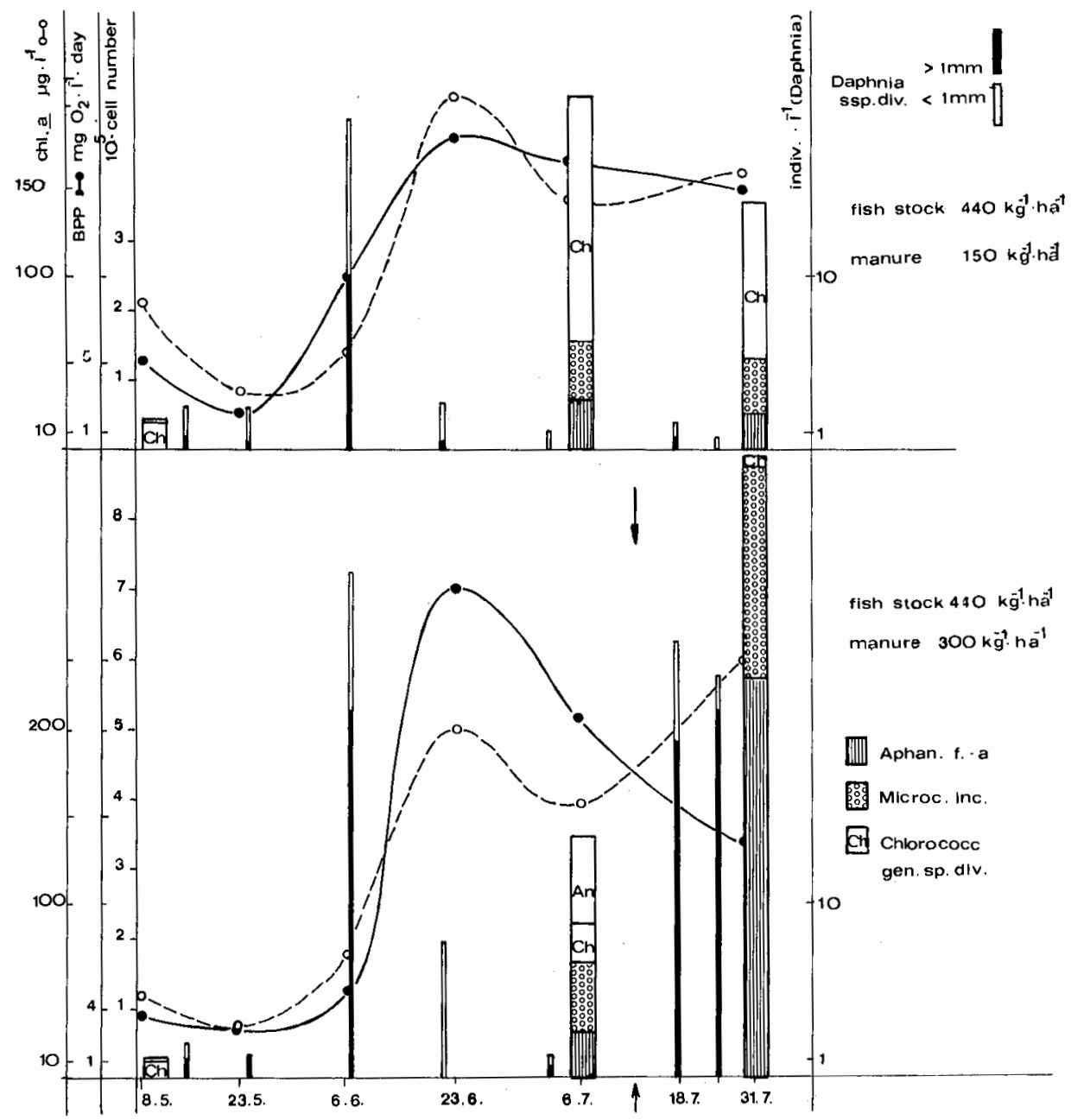

Figure 4. Experiment with differently manured but equally stocked pools. The arrow indicates the day on which most of fish died. 
increased, the Crustaceoplankton is diminished and small green algae are able to grow and outcompete Aphanizomenon. However, when the fishstock is small, the Aphanizomenon bloom persists for the entire summer.

The results from the experiments corroborate the controlling effect of Crustaceoplankton on phytoplankton diversity and appearance of Aphanizomenon.

Figure 2 shows the results of an experiment in plastic bags hanging in the buoy in pond water. At that time, the pond was full of Potamogeton pusillus and Hydrodictyon, the water contained only small amount of algae and about 30 Daphnia specimens per 1 . We removed the zooplankton from the half of the bags. The concentration of nutrients did not influence the species composition of the algae. The main reason of the bloom of Aphanizomenon was evidently presence of filtrating crustacea. Figure 3 presents two cases from the experiment, performed in artificial enclosures of plastic, with the natural bottom, of about $3 \mathrm{~m}^{2}$ of surface area. The water in a shallow pond contained the mixture of Aphanizomenon and green algae. The first two parallels were overstocked. Other parallels served as a control. Overstocked parallels changed almost immediately and after a few days, they presented a high primary production and chlorophyll concentration, contained small green algae and few Daphnia specimens. Aphanizomenon appeared only in the control without fish and showed very low primary production.

Another experiment was performed in artificial ponds made of concrete but with natural soil on the bottom (fig.4). The experiment was performed for other purposes and only two pools with different manure fertilization were chosen to demonstrate the effect mentioned above. The fish stock was too dense as to maintain the monospecific Aphanizomenon population. In the second pool, the manuring was so heavy, that in the beginning of July most of fish died. The number of Daphnia increased immediately and heavy water bloom of Aphanizomenon appeared.

It can be concluded that at least three factors are necessary to bring about blooms of Aphanizomenon in a fish-pond system:

1. A suitable concentration of nutrients must be present.

2. A fish stock of up to $200 \mathrm{~kg} \cdot \mathrm{ha}^{-1}$ which reaches the seasonal mean total mass of the fish up to $350 \mathrm{~kg} \cdot \mathrm{ha}^{-1}$.

3. An inoculum of Aphanizomenon must be present in sufficient amount, otherwise other colonial algae like Pediastrum, Coelastrum, or other filamentous blue-greens will occupy the free niche. (Autorreferat)

\section{REFERENCES}

1 Boyd, C.E.: Phosphorus dynamics in ponds. Proc. 25th Ann. Conf. Southeast. Ass. Game and Fish Comm. 1971, 418-426 (1971).

2 Hrbácek, J.: Contribution to the ecology of water-bloom-forming blue-green algae - Aphanizomenon flos-aquae and Microcystis aeruginosa. Verh. int. Verein. Limnol. 15, 837-846 (1964).

3 Murr, L.R., Gons, H.J., and van Liere, L.: Some experiments on the competition between green algae and blue-green bacteria in light limited environments. FEMS Microbiol. Lett. I, 335-338 (1977).

Address of the author: Dr. Jaroslava Komárková, Institute of Botany, Dukelska 145, 37982 Třeboň, CSSR. 
Diskussion. Die Rolle der einzelnen Faktoren bei der Entwicklung der Aphanizomenon-Wasserblüten steht im Mittelpunkt. Meffert: Wird Aphanizomenon gelegentlich von Grünalgen verdrängt, weil sie konkurrenzfähiger sind, oder/und wird Aphanizomenon auch direkt von Grünalgen unterdrückt? Komárková: Eine Nährstofflimitierung für Autotrophe besteht in diesen Teichen nicht. Crustaceen bevorzugen aber Grünalgen; aus einer Mischung planktischer Grünalgen und Aphanizomenon fressen Daphnien die ersteren weg. Direkte Hemmung von Aphanizomenon durch Grünalgen konnte ich nie feststellen. Komárek unterstreicht die Bedeutung des Fischbesatzes für die Kontrolle auch der Aphanizomenon-Wasserblüten. Cronberg: Auch die Art der Fische ist bedeutsam: Erfahrungen in Schweden zeigten, dass Fische, die Bodenvegetation fressen, andere Auswirkungen haben als solche, die hauptsächlich Plankton fressen. Mollenhauer erkundigt sich nach der höheren Vegetation der Teiche. Komárková: Höhere Pflanzen müssen künstlich entfernt werden.

Uehlinger, U.: Phosphorus requirements of the blue-green alga Aphanizomenon flosaquae (poster lecture)

As a consequence of the increased eutrophication blooms of Aphanizomenon flosaquae are appearing more frequently in Swiss lakes [1,3].

To investigate the phosphorus demands of the alga, a clone of Aphanizomenon flosaquae var. klebahni (isolated by Dr. A. Zehnder, EAWAG, from the Greifensee) was cultured in chemostats under continuous illumination $\left(110 \mu \mathrm{m}\right.$ Einstein $\left.\mathrm{m}^{-2} \mathrm{~s}^{-1}\right)$ at $23^{\circ} \mathrm{C}[2]$.

In batch cultures without phosphate limitation a growth rate $\left(\mu_{\max }\right)$ of $0.0589 \mathrm{~h}^{-1}$ was observed (light $110 \mu \mathrm{E} \cdot \mathrm{m}^{-2} \mathrm{~s}^{-1}$, temperature $23^{\circ} \mathrm{C}$ ).

Under phosphate limitation a $\mathrm{K}_{\mathrm{s}}$ value of $1,5 \mu \mathrm{g} \mathrm{PO}_{4}-\mathrm{P} / 1$ was estimated by fitting the Monod equation. It was also possible to describe the growth rate as a function of the phosphorus cell quota.

The comparison of our results with datas from other authors shows, that with few exceptions, other freshwater algae have similiar phosphorus demands.

The experimental datas confirm, that in a mesotrophic lake an Aphanizomenon bloom can take place, even though no phosphate is detectable. This is due mainly to the epilimnetic phosphorus cycle. (Autorreferat)

\section{REFERENCES}

1 Uehlinger, U.: Untersuchungen zur Autökologie der planktischen Blaualge Aphanizomenon flosaquae. PhD Thesis ETH Zürich Nr.6723 (1980).

2 Uehlinger, U.: Experimentelle Untersuchungen zur Autökologie von Aphanizomenon flos-aquae. Arch. Hydrobiol., Suppl. 60 (3), Algol. Studies 28, 260-288 (1981).

3 Uehlinger, U.: Zur Ökologie der planktischen Blaualge Aphanizomenon flos-aquae in Alpenrandseen. Schweiz. Z. Hydrol. 43 (1), 69-88 (1981).

Address of the author: Dr. U. Uehlinger, Seenforschungslaboratorium der EAWAG/ETHZ, CH-6047 Kastanienbaum, Switzerland.

Schanz, F.: Beobachtete und potentielle Blaualgenentwicklung im Hastings Lake (Edmonton, Alberta, Canada). (Der Autor wird zusammen mit P.R. Gorham die Arbeit an anderer Stelle ausführlich publizieren) 
Hastings Lake ist ein seichter, eutropher See im Prairie-Parkland von Alberta (mittlere Tiefe: $2,5 \mathrm{~m}$, maximale Tiefe: $8 \mathrm{~m}$, Oberfläche: $8,71 \mathrm{~km}^{2}$, Einzugsgebiet: $90 \mathrm{~km}^{2}$ ). Oberflächlicher $\mathrm{Zu}$ - und Abfluss von Wasser nur im Frühjahr unmittelbar nach der Schneeschmelze; die Wasserzufuhr während des Sommers erfolgt durch salzreiche Grundwasserströme und Regen auf die Seeoberfläche.

Im Jahre 1978 führten wir von April bis Oktober neun Probenahmen durch. Unmittelbar anschliessend wurden sechs verschiedene Biotests in abgeschlossenen Gefässen angesetzt (in belüfteten 1000-ml-Delong-Flaschen mit $750 \mathrm{ml}$ Kulturwasser und in unbelüfteten 150-ml-Delong-Flaschen mit $40 \mathrm{ml} \mathrm{Kulturwasser).} \mathrm{Einen}$ Teil der Kulturen beimpften wir mit einem Anabaena flos-aquae-Stamm aus der Sammlung von P.R. Gorham (A-1139 2). Die Delong-Flaschen stellten wir auf Schüttelapparate und belichteten von oben mit Fluoreszenzröhren (Intensität: $\left.28 \mu \mathrm{E} \mathrm{m}^{-2} \mathrm{~s}^{-1}\right)$. Nach etwa drei Wochen wurden die Versuche abgebrochen und die vorhandene Biomasse als Trockengewicht bestimmt. Im Seewasser selbst verfolgten wir die Entwicklung der Biomasse sowie den Anteil von drei Blaualgengattungen (Anabaena, Microcystis und Oscillatoria) an der gesamten Algenpopulation.

Wir konnten im See eine Zunahme der Biomasse von April bis Juli feststellen (April: 2,8 mg Trockengewicht $\mathrm{l}^{-1}$; Juli: 45,7 $\mathrm{mg} \mathrm{l}^{-1}$ ). Während der Monate Juli und August dominierten Blaualgen, wobei nur den drei obengenannten Gattungen eine gewisse Bedeutung zukam. Es war möglich, die Ergebnisse der Experimente, welche mit unbeimpftem Rohwasser durchgeführt wurden, mit der Biomasseentwicklung im See in Verbindung zu bringen: Hohe Produktionswerte (= Biomasse bei Versuchsende minus Biomasse bei Versuchsbeginn) im Biotest wurden dann erhalten, wenn die Biomasse im See zunahm, niedrige Produktionswerte stellten wir bei abnehmender Biomasse fest. Mit Hilfe von Anabaena flos-aquae A-1139, massen wir die Produktionskraft (algal growth potential) des filtrierten oder autoklavierten Hastings-Lake-Wassers. Von April bis Juli war eine starke Abnahme festzustellen

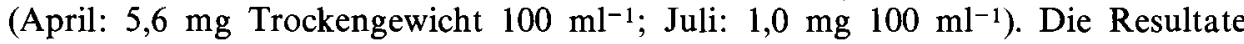
deuten darauf hin, dass während dieser Periode bestimmte Substanzen aufgebraucht werden, welche das Wachstum von Anabaena flos-aquae A-1139 2 förderten. In Kulturen mit Algenmischpopulationen konnte dies nicht festgestellt werden, da - je nach Nährstoffangebot - verschiedene Arten im Wachstum gefördert werden und sich deshalb die Biomasse bis zum Versuchsende so lange nur geringfügig ändert, als für eine oder mehrere Arten genügend Nährstoffe vorhanden sind, was bis Juli offensichtlich der Fall war. Zur Ermittlung wachstumsbegrenzender Faktoren wurden Biotests mit Anabaena flos-aquae A-1139, 2 in filtiertem Hastings-LakeWasser durchgeführt, wobei wir Eisen und/oder Phosphor zugaben. Die Versuche zeigten, dass in der Periode Juli bis Oktober eine oder beide Substanzen wachstumsbegrenzend waren.

Wegen der hohen Wassertemperatur und des hohen Sauerstoffgehaltes von der Oberfläche bis zum Grund muss im Hastings Lake während der Sommermonate mit einer raschen Mineralisation abgestorbener Plankter gerechnet werden. Dadurch stehen die Nährstoffe schon nach kurzer Zeit wieder zur Verfügung, was die hohen Produktionswerte während einer langen Periode erklärt. Ausserdem dürfte der Grundwasserstrom etwas Nährstoffe in den See bringen. Der starke Rückgang der Biomasse im August war vermutlich sowohl nährstoff- als auch witterungsbedingt 
(20. Juli: $45,7 \mathrm{mg}$ Trockengewicht $1^{-1} ; 9$. August: $27,1 \mathrm{mg} \mathrm{1}^{-1}$; 29. August: $13,7 \mathrm{mg}$ $\left.1^{-1}\right)$ : Wie schon oben erwähnt, zeigte sich in Biotests, dass Eisen und Phosphor das Wachstum von Anabaena flos-aquae A-1139 2 begrenzten. Die beiden Substanzen dürften das Algenwachstum auch unter natürlichen Bedingungen beeinflusst haben. Ausserdem nahmen im Monat August Lufttemperatur und Sonnenscheindauer ab, was die Intensität der Produktion sicher wesentlich mitbestimmt hat (mittlere Lufttemperatur 21 .Juli bis 9 . August: $17,2^{\circ} \mathrm{C}, 10$. August bis 29 . August: $12,7^{\circ} \mathrm{C}$; mittlere Sonnenscheindauer 21.Juli bis 9 . August: $11,4 \mathrm{hd}^{-1} ; 10$. August bis 29 . August: $6,8 \mathrm{hd}^{-1}$ ). (Autorreferat)

Adresse des Autors: Dr. F. Schanz, Limnologische Station der Universität Zürich, Seestrasse 187, CH-8802 Kilchberg, Schweiz.

Diskussion. Die Arbeit steht in Zusammenhang mit Studien, welche eine Prognose tuber die in einem See im Laufe eines Sommers zu erwartende Entwicklung planktischer Blaualgen ermöglichen sollen. Das ist, wie auf Fragen zu erfahren war, besonders wünschenswert in Regionen, in denen nicht selten toxische Wasserblüten auftreten.

\section{Exkursionen}

\subsection{Grimsel-Gotthard}

Route: Alpnach-Brünig-Meiringen-Aareschlucht-Grimselpass-Gletsch-Nufenenpass-Airolo-Gotthardpass-Brunnen-Luzern.

\section{Wichtigste Sammelstellen}

Aareschlucht bei Meiringen, Kt. Bern. LK 1:25000, Blatt 1210, Koord. 658.600/ $174.600,610 \mathrm{~m}$ ü. M. Unterlage: Malmkalke des autochthonen Sedimentmantels des Aarmassivs. Tintenstriche verschiedener Benetzungsgrade, Tropfstellen, feuchte Felswände.

Grimsel-Passhöhe, beim Totesee. LK 1:25000, Blatt 1250, Koord. 668.800/157.000, $2165 \mathrm{~m}$ ü. M. Unterlage: Zentraler Aaregranit des Aarmassives.

Kleine Bächlein mit Aufwuchs.

Nufenenpass: Wasserfall unterhalb der Zapei della $\mathrm{Ca}$, etwa $1,5 \mathrm{~km}$ östlich der Passhöhe. LK 1:25000, Blatt 1251, Koord. 674.400/148.000, 2300 m ü. M. Unterlage: Paragneise des Gotthardmassivs. Von Wasserfilmen überrieselte bis trockene, extremer Belichtung ausgesetzte Gneisblöcke und Wände. Günstig zum Sammeln von Stigonema.

\subsection{Klewenalp}

Route: Beckenried-Klewen-Niederrickenbach-Dallenwil.

\section{Sammelstellen}

Klewenalp: Stafelbach bei Stafelhütte. LK 1:25000, Blatt 1171, Koord. 679.250/ $197.880,1540$ m ü. M. Unterlage: Kalk 
Klewenalp: Fellbach. LK 1:25000, Blatt 1171, Koord. 678.300/197.480, $1580 \mathrm{~m}$ ü. M. Unterlage: Kalk.

An beiden Stellen Chamaesiphon polonicus, Ch. polymorphus, Homoeothrix varians, Hydrurus foetidus u. a.

\subsection{Gerzensee-Wolfenschiessen}

Route: Kernwald-Gerzensee-Blindseeli-Stans-Wolfenschiessen.

\section{Sammelstellen}

Gerzensee, Kernwald, Kt. Obwalden. LK 1:25000, Blatt 1170, Koord. 664.950/ $197.330,580 \mathrm{~m}$ ü. M.

Synechococcus diatomicola, Tetrarcus ilsteri, Cyanothece aeruginosa, Synechocystis septentrionalis u.a. [7]*.

Bergs bei Wolfenschiessen, Kt. Nidwalden. LK 1:25000, Blatt 1190, Koord. $671.800 / 193.000,560 \mathrm{~m}$ ü. M. Unterlage: Gehängeschutt (Kalk).

Oocardium.

\section{Rückblick und Ausblick}

Das wichtigste Ereignis dieses 8. Symposiums der IAC war die Begegnung zwischen «Cyanophytologen» und «Cyanobacteriologen». Vorderste Exponenten beider Richtungen führten intensive Gespräche.

Die Spaltung der «Cyanotaxonomen» in zwei völlig getrennte, voneinander unabhängige Schulen, die zeitweise bevorzustehen schien, wäre verhängnisvoll gewesen. Der Berichterstatter steht unter dem Eindruck, das habe nicht nur vermieden werden können, sondern die Vertreter beider Richtungen seien bereit, voneinander zu lernen und auf dem Wege der Erforschung der Blaualgen auch bei in Einzelfragen auseinandergehenden Meinungen doch gemeinsam voranzugehen.

Um die Arbeit der IAC zukünftig breiter abzustützen, wurde ein Ausschuss gebildet. Ihm gehören an:

Frau Fil. lic. Gertrud Cronberg, Institute of Limnology FACK, S-22003 Lund, Schweden;

Prof. Dr. Konstantin Anagnostidis, Institut für Systematische Botanik, Universität Athen, Panepistimiopolis, Athen 621, Griechenland;

Prof. Dr. Stjepko Golubić, Dept. of Biology, Boston University, 2 Cummington St., Boston, Mass. 02215, USA;

Dr. Jiří Komárek, Botanisches Institut der ČSAV, Hydrobotanische Abteilung, Dukelská 145, CS-37982 Třeboň, ČSSR;

Dr. Dieter Mollenhauer, Forschungsinstitut Senckenberg, Aussenstelle Lochmühle, D-6465 Biebergemünd, BRD;

Dr. Alfons Zehnder, Fachabteilung für Hydrobiologie-Limnologie, EAWAG, CH-8600 Dübendorf.

Ein 9. Symposium der IAC wird vom 10. bis 19. August 1983 wieder in Kastanienbaum stattfinden. Es wird unter der wissenschaftlichen Leitung von Prof. Dr. St. Golubić stehen. 


\section{LITERATURVERZEICHNIS}

1 Anagnostidis, K.: Untersuchungen über die Cyanophyceen einiger Thermen in Griechenland, S. 1322. Thessaloniki 1961.

2 Bourrelly, P.: Les Algues d'Eau Douce. Boubée \& Cie, Paris 1970.

3 Desikachari, T.V.: Cyanophyta. I.C.A.R., New Delhi. Academic Press, London 1959.

4 Friedrich, G.: Ókologische Untersuchungen an einem thermisch anomalen Fliessgewässer: Erft, Niederrhein. SchrReihe Landesanst. Gewässerkde u. Gewässerschutz NW 33, 1-125 (1973).

5 Geitler, L.: Cyanophyceae. In: Rabenhorst's Kryptogamenflora, Bd. 14, S. 1196. Leipzig 1932.

6 Golubić, S.: Algenvegetation der Felsen. In: Die Binnengewässer, Bd. XXIII, S. 183. Stuttgart 1967.

7 Hindák, F.: Morphological variability and taxonomy of some coccoid blue-green algae (Cyanophyta). Schweiz. Z. Hydrol. (im Druck).

8 Jaag, O.: Untersuchungen über die Vegetation und Biologie der Algen des nackten Gesteins in den Alpen, im Jura und im Schweizerischen Mittelland. Beitr. KryptogFlora Schweiz 9 (3), 1-560 (1945).

9 Kann, E.: Systematik und Ökologie der Algen österreichischer Bergbäche. Arch. Hydrobiol., Suppl. 53, H. 4, 405-643 (1978).

10 Staub, R.: Untersuchungen an der Blaualge Oscillatoria rubescens DC. Schweiz. Z. Hydrol. 23, 83198 (1961).

11 Zehnder, A.: Ein Blick auf Leben und Werk von Otto Jaag. Mskr.-Kopien beim Autor erhältlich (1979).

12 Zehnder, A.: 7. Symposium über Fragen der Cyanophytentaxonomie in Lednice (ČSSR), 29.Juli bis 8. August 1976. Schweiz. Z. Hydrol. 39, (2), 114-151 (1977).

Adresse des Berichterstatters: Dr. Alfons Zehnder, Fachabteilung Hydrobiologie-Limnologie, EAWAG, CH-8600 Dübendorf. 